\title{
Facile synthesis of some 5-(3-substituted-thiophene)- pyrimidine derivatives and their pharmacological and computational studies
}

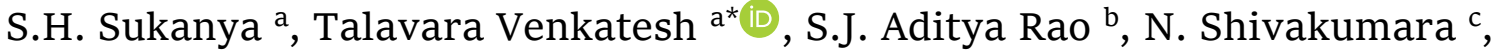 Muthipeedika Nibin Joy ${ }^{\mathrm{d}}$}

a: Department of P.G. Studies and Research in Chemistry, Jnanasahyadri, Kuvempu University, Shankaraghatta 577451, Karnataka, India

b: Plant Cell Biotechnology Department, CSIR-Central Food Technological Research Institute, Mysore 570020, Karnataka, India

c: Department of Chemistry, Ramaiah Institute of Technology, Bangalore 560054, India

d: Innovation Center for Chemical and Pharmaceutical Technologies, Institute of Chemical Technology, Ural Federal University, 19 Mira St., Yekaterinburg 620002, Russia

* Corresponding author: venkateshatalwar@gmail.com

This article belongs to the regular issue.

(C) 2021, The Authors. This article is published in open access form under the terms and conditions of the Creative Commons Attribution (CC BY) license (http://creativecommons.org/licenses/by/4.o/).

\begin{abstract}
A series of 5-(3-substituted-thiophene)-pyrimidine derivatives (3a-d) were synthesized via Knoevenagel condensation reaction in aqueous ethanol using $\mathrm{H}_{2} \mathrm{O}_{2}: \mathrm{HCl}$ as a catalyst. Their pharmacological effects were evaluated. Analytical and spectroscopic methods confirmed the structures of the target molecules. The antibacterial activity studies revealed that compounds $\mathbf{3} \mathbf{b}$ and $\mathbf{3} \mathbf{d}$ exhibited the most effective zone of inhibition against bacterial strains $E$. coli and $S$. aureus, respectively. The in vitro cytotoxicity was carried out by MTT assay against MCF-7 cell line. The results showed the excellent selectivity for all four compounds, among which the compound 3a exhibited remarkable cytotoxicity with a minimum cell viability range of 23.68 to $44.16 \%$. The interaction of compounds with calf thymus DNA was determined using UV-absorption spectroscopy. The results confirmed that all the synthesized compounds interacted strongly with CT DNA through electrostatic or groove binding. In silico ADME-toxicology studies indicated that all the molecules under investigation are nontoxic with good oral bioavailability. The drug-likeness score indicated that they are suitable as drug-leads. In silico molecular docking the specified compound $\mathbf{3 b}$ bounds with GlcN-6-P and P38 MAPk with a minimum binding energy of -7.9 and $-6.4 \mathrm{kcal} / \mathrm{mol}$, respectively. DFT study demonstrated that the compound $\mathbf{3 d}$ was chemically and biologically more reactive due to less energy gap.
\end{abstract}

\author{
Keywords \\ biological studies \\ DNA binding \\ ADME-toxicology study \\ SAR study \\ molecular docking and DFT \\ studies
}

\section{Introduction}

Heterocyclic compounds play a predominant role in medicinal chemistry and synthetic organic chemistry due to their massive biological importance. The synthesis of nitrogen and sulphur containing fused heterocyclic compounds with multi-structures in one molecule has attracted the attention of medicinal chemists and researchers due to their multifaceted pharmacological activities [1-2]. Among them, pyrimidine and thiophene have been recognized as key scaffolds owing to their important biological significances and interesting therapeutic properties including anti-tubercular [3], anticancer [4], anti-HIV [5], antibacterial [6], antifungal [7], antitumor [8], also used as potent EGFR inhibitor [9, 10], protein kinase inhibitors [11-14] and 5-HT7 receptors [15].

Moreover, the heterocyclic compounds increase the strength of the molecules by forming hydrogen bonds with DNA. Hence, the interactive study of heterocyclic moieties with DNA is essential for estimating their anticancer activity and elucidates the viable mechanism of their action. Therefore, DNA binding is considered as an essential ex- 
perimental step to measure anticancer drugs activity because most anticancer drugs specifically target the DNA [16]. Heterocyclic compounds appear to be most effective against various cancers. Around $60 \%$ of the medicines used for cancer treatment are based on heterocyclic moieties. Among the various heterocyclic moieties, nitrogen and sulphur-based compounds are effective against different types of cancers [17-19].

Cancer is a group of diseases in which the abnormal cells grow uncontrollably by disregarding the normal rules of cell division. Cancer is caused by many external (tobacco, chemicals, radiation and infectious organisms) as well as some internal factors (inherited mutations, hormones, immune conditions and random mutations). There are different types of cancer such as breast cancer, bladder cancer, kidney cancer, leukaemia, liver cancer, lung cancer, melanoma, pancreatic cancer, prostate cancer, thyroid cancer etc. [20]. The breast cancer is one of the most frequently diagnosed cancers and the leading cause of death in females worldwide, with more than 1.5 million new cases recorded every year. It is also the fifthhighest cause of death in the world [21]. The modern methods of chemotherapy suffer from the main disadvantages: side effects and drug resistance. Therefore, continued search for novel and safer anticancer drugs remains essential [22].

Pollution is one of the critical problems that the synthetic organic chemist faces in designing the organic reactions for the synthesis of pharmacologically active compounds. Thus, development of an environmentally-friendly chemical process that induces necessary organic transformation is one of the most important goal of sustainable progression [23]. Therefore, "green chemistry" becomes a promising approach that meets the requirements of the chemical and pharmaceutical industries. The replacement of hazardous solvents with eco-friendly solvents is an acceptable and valuable approach in a chemical reaction. Hence, the use of a hypochlorous acid ( $\mathrm{HOCl})$ as a green halogenating agent [24] is highly advantageous over other catalysts, including cost-effectiveness, efficiency and readily availability. Earlier, our research group has reported the synthesis of different pyrimidine derivatives and other biologically important heterocyclic compounds [25-27]. Some of the drugs containing pyrimidine nucleus available in the market are depicted below (Fig. 1).

Based on the above findings, we herein report the application of $\mathrm{H}_{2} \mathrm{O}_{2}: \mathrm{HCl}$ as a green halogenating catalyst for the synthesis of 5-(3-substituted-thiophene)-pyrimidine derivatives of considerable pharmacological relevance.

\section{Experimental}

\subsection{Materials and Method}

All chemicals and calf thymus DNA were purchased from Aldrich Chemical Company, and the reaction was performed at refluxed condition and solvents were used without further purification. Analytical TLC was performed with E. Merck silica gel GF254 glass plates. Visualization of the developed chromatogram was performed by UV light (254 and $356 \mathrm{~nm}$ ). The melting points of the products were determined in open capillary tubes and uncorrected. The ATR-IR spectra were obtained using Bruker FTIR Alpha spectrometer. The ${ }^{1} \mathrm{H}$ NMR and ${ }^{13} \mathrm{C}$ NMR spectra were recorded on Bruker $400 \mathrm{MHz}$ and $100 \mathrm{MHz}$ in $\mathrm{DMSO}-\mathrm{d}_{6}$ as a solvent. Mass spectra were obtained by Agilent 1200 series LC and Micromass Q spectrometer. The DNA binding studies were carried on Elico SL 159 UV-Visible spectrophotometer in 200-500 $\mathrm{nm}$ range equipped with $1.0 \mathrm{~cm}$ quartz cell at room temperature. The anticancer activity was carried out in the Department of Microbiology, Maratha Mandal's NGH Institute of Dental Sciences and Research Centre, Belgaum, Karnataka. The computational studies were carried out by Density functional theory (DFT)/B3LYP method using Gaussian og software using 6$31 \mathrm{G}(\mathrm{d}, \mathrm{p})$ basis set at gaseous phase.

\subsection{General procedure for the synthesis of 5-(3- substituted-thiophene)-pyrimidine derivatives (3a-d)}

The synthesis of 5-(3-substituted-thiophene)-pyrimidine derivatives (3a-d) were carried out by the reaction of barbituric/thiobarbituric acid (1,1mmol) with 3-substitutedthiophene-2-carboxaldehyde $(2,1 \mathrm{mmol})$ in the presence of $15 \mathrm{~mL}$ aqueous ethanol using $6 \% \mathrm{H}_{2} \mathrm{O}_{2}: \mathrm{HCl}(2: 1)$ as a catalyst. The reaction mixture was refluxed at $80{ }^{\circ} \mathrm{C}$ for about 10-15 $\mathrm{min}$ and the progress of the reaction was monitored by TLC (Ethyl acetate and Petroleum ether). After the completion of the reaction, the reaction mixture was cooled to room temperature and poured into the $100 \mathrm{~mL}$ flake ice with vigorous stirring to get solid precipitated out. The crude mixture was filtered, washed and recrystallized with absolute ethanol to afford pure solid products.

\subsubsection{5-(Thiophen-2-ylmethylidene)pyrimidine- $2,4,6(1 \mathrm{H}, 3 \mathrm{H}, 5 \mathrm{H})$-trione (3a)}

Yield: 96\%, Yellow solid; MP: $280-282^{\circ} \mathrm{C}$. IR (ATR, v cm$\left.{ }^{-1}\right): 3373(\mathrm{NH}), 1654(\mathrm{C}=\mathrm{O}), 1529(\mathrm{C}=\mathrm{C}) .{ }^{1} \mathrm{H}$ NMR (400 MHz, DMSO-d6, $\delta$ ppm): 7.31-7.33 (t, $J=8 \mathrm{~Hz}, 1 \mathrm{H}, \mathrm{Ar}-\mathrm{H}$ ), 8.13-8.24 (m, 2H, Ar-H), $8.53(\mathrm{~s}, 1 \mathrm{H}, \mathrm{CH}), 11.17(\mathrm{~s}, 1 \mathrm{H}, \mathrm{NH})$, 11.21 (s, $1 \mathrm{H}, \mathrm{NH}) .{ }^{13} \mathrm{C}$ NMR (10O MHz, DMSO-d $\left.6, \delta \mathrm{ppm}\right)$ : $112.035,128.808,136.776,142.526,146.116,146.291$, 150.679, 163.453 and 163.950 (C=O). HRMS: $m / z 221.9054$ $[\mathrm{M}+\mathrm{H}]^{+}$. Anal. Calcd for $\mathrm{C}_{9} \mathrm{H}_{6} \mathrm{~N}_{2} \mathrm{O}_{3} \mathrm{~S}: \mathrm{C} 48.64, \mathrm{H} 2.72$ and $\mathrm{N}$ 12.61\%. Found: C 48.59, H 2.68 and N 12.53\%.

\subsubsection{5-[(3-Methylthiophen-2-yl)methylidene]pyrimidine- 2,4,6(1H,3H,5H)-trione (3b)}

Yield: 94\%, Yellow solid; MP: 302-306 ${ }^{\circ} \mathrm{C}$. IR (ATR, $\left.\mathrm{u} \mathrm{cm}{ }^{-1}\right): 3225(\mathrm{NH}), 2858\left(\mathrm{CH}_{3}\right), 1703(\mathrm{C}=\mathrm{O}), 1542(\mathrm{C}=\mathrm{C}) .{ }^{1} \mathrm{H}$ NMR (4OO MHz, DMSO-d6, $\delta$ ppm): 2.24 (s, 3H, $\mathrm{CH}_{3}$ ), 7.21-7.23 (d, $J=8 \mathrm{~Hz}, 1 \mathrm{H}, \mathrm{Ar}-\mathrm{H}$ ), 8.16-8.18 (d, J= $8 \mathrm{~Hz}, 1 \mathrm{H}, \mathrm{Ar}-\mathrm{H}$ ), 8.53 (s, $1 \mathrm{H}, \mathrm{CH}), 11.17$ (s, 1H, NH), $11.24(\mathrm{~s}, 1 \mathrm{H}, \mathrm{NH}) .{ }^{13} \mathrm{C}$ NMR (10O MHz, DMSO-d $6, \delta \mathrm{ppm}): 19.922\left(\mathrm{CH}_{3}\right), 114.870,135.252$, 136.011, 145.166, 147.180, 154.915, 158.106, 167.728 and 168.497 (C=O). HRMS: $m / z$ 235.9774 $[\mathrm{M}+\mathrm{H}]^{+}$. Anal. Calcd for $\mathrm{C}_{10} \mathrm{H}_{8} \mathrm{~N}_{2} \mathrm{O}_{3} \mathrm{~S}$ : C 50.84, H 3.41 and N 11.86\%. Found: C 50.79, H 3.36 and $\mathrm{N} 11.80 \%$. 
<smiles>O=c1[nH]cc(F)c(=O)[nH]1</smiles>

5-Fluorouracil (Anticancer)<smiles>O=c1[nH]c(=O)n(C2CCCO2)cc1F</smiles>

Tegafur (anticancer)<smiles>O=c1[nH]c(=O)n(C2CC(O)C(CO)O2)cc1F</smiles><smiles>O=c1[nH]cc(S)c(=O)[nH]1</smiles>

5-thiouracil (Anticancer)<smiles>O=c1[nH]cc(N(CCCl)CCCl)c(=O)[nH]1</smiles>

Uramustine (Anticancer)<smiles>COc1cc(Cc2cnc(N)nc2N)cc(OC)c1O</smiles><smiles>CS(=O)(=O)N1CCN(Cc2cc3nc(-c4cccc5[nH]ncc45)nc(N4CCOCC4)c3s2)CC1</smiles><smiles>CC(=O)Nc1cc(-c2ccnc3cc(C(=O)c4cccs4)nn23)ccc1F</smiles><smiles></smiles>

Fig. 1 Some of the drugs containing pyrimidine nucleus available in the market

\subsubsection{5-(Thiophen-2-ylmethylidene)-2- thioxodihydropyrimidine-4,6(1H,5H)-dione (3c)}

Yield: 93\%, Green solid; MP: $320-322^{\circ} \mathrm{C}$. IR (ATR, $\left.v \mathrm{~cm}^{-1}\right): 3106(\mathrm{NH}), 1760(\mathrm{C}=\mathrm{O}), 1559(\mathrm{C}=\mathrm{C}), 1156(\mathrm{C}=\mathrm{S})$. ${ }^{1} \mathrm{H}$ NMR (400 MHz, DMSO-d 6 , $\delta \mathrm{ppm}$ ): 6.86-6.88 (d, $J=8 \mathrm{~Hz}, 1 \mathrm{H}, \mathrm{Ar}-\mathrm{H}), 8.20(\mathrm{~s}, 1 \mathrm{H}, \mathrm{CH}), 8.34-8.36(\mathrm{~d}$, $J=8 \mathrm{~Hz}, 2 \mathrm{H}, \mathrm{Ar}-\mathrm{H}), 12.2 \mathrm{O}(\mathrm{s}, 1 \mathrm{H}, \mathrm{NH}), 12.30(\mathrm{~s}, 1 \mathrm{H}, \mathrm{NH})$. ${ }^{13} \mathrm{C}$ NMR (100 MHz, DMSO-d $\left.6, \delta \mathrm{ppm}\right): 114.713,116.139$, $124.434,139.254,157.012,160.480,162.825,164.168$ $(\mathrm{C}=\mathrm{O})$ and $178.617(\mathrm{C}=\mathrm{S})$. HRMS: $\mathrm{m} / z$ 237.9467 $[\mathrm{M}+\mathrm{H}]^{+}$. Anal. Calcd for $\mathrm{C}_{9} \mathrm{H}_{6} \mathrm{~N}_{2} \mathrm{O}_{2} \mathrm{~S}_{2}$ : $\mathrm{C} 45 \cdot 36, \mathrm{H} 2.54$ and $\mathrm{N} 11.76 \%$. Found: C 45.30, H 2.49 and N 11.71\%.

\subsubsection{5-[(3-Methylthiophen-2-yl)methylidene]-2- thioxodihydropyrimidine-4,6(1H,5H)-dione (3d)}

Yield: 95\%, Green solid; MP: $310-312{ }^{\circ} \mathrm{C}$. IR (ATR, $v \mathrm{~cm}^{-1}$ ): $3108(\mathrm{NH}), 2852\left(\mathrm{CH}_{3}\right), 1704(\mathrm{C}=\mathrm{O}), 1516(\mathrm{C}=\mathrm{C}), 1200$ $(\mathrm{C}=\mathrm{S}) .{ }^{1} \mathrm{H}$ NMR $\left(400 \mathrm{MHz}, \mathrm{DMSO}-\mathrm{d}_{6}, \delta \mathrm{ppm}\right): 2.24(\mathrm{~s}, 3 \mathrm{H}$, $\left.\mathrm{CH}_{3}\right), 7.22-7.24(\mathrm{~d}, J=8 \mathrm{~Hz}, 1 \mathrm{H}, \mathrm{Ar}-\mathrm{H}), 8.17-8.19$ (d, $J=8 \mathrm{~Hz}, 1 \mathrm{H}, \mathrm{Ar}-\mathrm{H}), 8.54(\mathrm{~s}, 1 \mathrm{H}, \mathrm{CH}), 11.18(\mathrm{~s}, 1 \mathrm{H}, \mathrm{NH})$, $11.25(\mathrm{~s}, 1 \mathrm{H}, \mathrm{NH}) .{ }^{13} \mathrm{C}$ NMR (100 MHz, DMSO-d $6, \delta \mathrm{ppm}$ ): 26.806 $\left(\mathrm{CH}_{3}\right), 114.280,128.031,128.903,129.867,130.391$, 130.892, 142.472, $163.552(\mathrm{C}=\mathrm{O})$ and $173.358(\mathrm{C}=\mathrm{S})$. HRMS: $m / z \quad 251.9608 \quad[\mathrm{M}+\mathrm{H}]^{+}$. Anal. Calcd for
$\mathrm{C}_{10} \mathrm{H}_{8} \mathrm{~N}_{2} \mathrm{O}_{2} \mathrm{~S}_{2}$ : C 47.6o, $\mathrm{H} 3.20$ and $\mathrm{N} 11.10 \%$. Found: $\mathrm{C}$ 47.55, $\mathrm{H} 3.16$ and $\mathrm{N} 11.06 \%$.

\subsection{Pharmacological studies}

\subsubsection{Antibacterial activity}

Antibacterial activity of the synthesized compounds (3a-d) was carried out by the agar well diffusion method [28] using two bacterial strains (Gram-negative and Grampositive) Escherichia coli (MTCC-1559) and Staphylococcus aureus (MTCC-902). DMSO was used as negative control and Ciprofloxacin as standard drug. The test compounds were dissolved in DMSO at two different concentrations, 20 and $40 \mu \mathrm{g} / \mathrm{mL}$

\subsubsection{Cytotoxicity}

In vitro cytotoxicity was assessed by the MTT assay method [29] against MCF-7 (Breast cancer) cell line. The cells were seeded in a 96-well flat-bottom microplate and maintained at $37{ }^{\circ} \mathrm{C}$ in $95 \%$ humidity and $5 \% \mathrm{CO}_{2}$ overnight. Different concentration (200, 100, 50, 25, 12.5 and $6.25 \mu \mathrm{g} / \mathrm{mL}$ ) of samples were treated. The cells were incubated for another $48 \mathrm{~h}$, and the wells were washed twice with PBS. $20 \mu \mathrm{L}$ of the MTT staining solution was added to each well, and the plate was incubated at $37^{\circ} \mathrm{C}$ for $4 \mathrm{~h}$. The medium with MTT was discarded, and $100 \mu \mathrm{L}$ of 
DMSO was added to each well to dissolve the formazan crystals. The absorbance was recorded at $570 \mathrm{~nm}$ using a microplate reader. The percentage of cell survival was calculated by using the following formula:

$$
\% \text { of cell survival }=\frac{\text { Mean O. D. of test compound }}{\text { Mean O. D. of Negative control }} \cdot 100 .
$$

\subsubsection{DNA binding study}

DNA binding study was assessed by using electronic spectroscopy. A solution of CT DNA in $50 \mathrm{mM}$ Tris- $\mathrm{HCl} / 50 \mathrm{mM}$ $\mathrm{NaCl}$ buffer solution was prepared at $\mathrm{pH}$ 6.9-7.01. In buffer solution, the ratio of absorption values of CT DNA at 260 and $280 \mathrm{~nm}$ is $1.8-1.9$, indicating that DNA was free of proteins [30]. Then a concentrated stock solution of DNA was prepared in $50 \mathrm{mM}$ Tris- $\mathrm{HCl}, 50 \mathrm{mM} \mathrm{NaCl}$ in double distilled water at $\mathrm{pH}$ 6.9-7.01. The concentration of CT DNA was determined per nucleotide by taking the absorption coefficient $\left(6600 \mathrm{dm}^{3} \mathrm{~mol}^{-1} \mathrm{~cm}^{-1}\right)$ at $260 \mathrm{~nm}$ [31]. Stock solutions were stored at $4{ }^{\circ} \mathrm{C} .2 \mathrm{~mL}$ of the solution was taken containing a fixed concentration of the compounds (3a-d) with CT DNA (o to $350 \mu \mathrm{L}$ of a 0.5025-6.0670 $10^{-7} \mathrm{M}$ stock CT DNA solution). A blank solution containing the same concentration of DNA was used as a reference. Solutions were prepared by mixing the compound and CT DNA in DMSO medium and then recording the UV absorption spectra by adding 25 to $350 \mu \mathrm{L}$ DNA to the compound. The spectra were recorded against a blank solution containing the same concentration of DNA (4.0909.10 $\left.0^{-6} \mathrm{~mol} \mathrm{~L}^{-1}\right)$. The intrinsic binding constant $\mathrm{Kb}$ was obtained by using the following equation [32]:

$$
\frac{[\mathrm{DNA}]}{\left(\epsilon_{\mathrm{A}}-\epsilon_{\mathrm{B}}\right)}=\frac{[\mathrm{DNA}]}{\left(\epsilon_{\mathrm{B}}-\epsilon_{\mathrm{F}}\right)}+\frac{1}{\mathrm{~K}_{\mathrm{b}}\left(\epsilon_{\mathrm{B}}-\epsilon_{\mathrm{F}}\right)^{\prime}}
$$

where, $\epsilon_{A}, \in_{B}$ and $\epsilon_{F}$ corresponds to the apparent, bound and free compound extinction coefficients, respectively. A plot of $\frac{[D N A]}{\left(\epsilon_{\mathrm{A}}-\epsilon_{\mathrm{F}}\right)}$ versus [DNA] gave a slope of $\frac{1}{\left(\epsilon_{\mathrm{B}}-\epsilon_{\mathrm{F}}\right)}$ and Y-intercept equal to $\frac{1}{\mathrm{~K}_{\mathrm{b}}\left(\epsilon_{\mathrm{B}}-\epsilon_{\mathrm{F}}\right)}$. Hence $\mathrm{K}_{\mathrm{b}}$ is the ratio of slope to intercept. The $\%$ of hyperchromicity or hypochromicity $(\% \mathrm{H})$ for the CT DNA/[Ligand] was obtained from $\left(\epsilon_{\mathrm{A}}-\epsilon_{\mathrm{F}}\right) / \epsilon_{\mathrm{F}} \cdot 100$.

\subsubsection{In silico oral bioavailability assessment and ADME- toxicology studies}

The oral bioavailability of the synthetic molecules (3a-d) can be predicted by considering their structural properties to screen based on the Rule of five or Lipinski rule-of-five (RO5) filter [33]. Rule of five employs the molecular properties necessary to filter candidate drug's pharmacokinetics (PK) and pharmacodynamics (PD) [34-36].

Oral bioavailability assessment was done using Osiris Data warrior V.4.4.3 [37] based on total molecular weight, ClogP, H-acceptors, H-donors, rotatable bonds as part of RO5 filters, along with TPSA (Topological polar surface area) and drug-likeness assessment [38]. Pharmacodynamic properties like mutagenicity, tumorigenicity, reproductive effects, irritancy, Ames toxicity and hepatotoxicity were predicted using the admetSAR server. Bioactivity scores were predicted using the molinspiration server for GPCR ligand, ion channel modulator, kinase inhibitor, nuclear receptor inhibitor, protease inhibitor, enzyme inhibitor. Pharmacokinetic properties like blood-brain barrier penetration, human intestinal absorption, Caco-2 permeability and CYP450 2D6 substrate were predicted by submitting each molecule individually to the admetSAR server [39].

\subsubsection{In silico molecular docking studies}

The docking of the synthesized compounds to the binding pocket of glucosamine-6-phosphate synthase (GlcN-6-P) and P38 MAP kinase was carried out using the AutodockVina program [40]. The co-crystallized structure of GlcN6-P (PDB ID: 2VF5) and P38 MAP kinase (PDB ID: 1OUK) were retrieved from protein databank, and their substrate binding sites were identified using pdbsum server [41, 42]. A grid box of dimensions $40 \times 50 \times 40 \AA$ with $\mathrm{X}, \mathrm{Y}$ and $\mathrm{Z}$ coordinates at $32.198,16.709$ and -3.151 for GlcN-6-P and $56 \times 60 \times 48 \AA$ with $\mathrm{X}, \mathrm{Y}$ and $\mathrm{Z}$ coordinates at 44.746 , 34.234 and 32.603 for P38 MAPk were created respectively. For the obtained molecules, all the torsions were allowed to rotate during docking. The grid box was set around the residues forming the active pocket. The binding interactions were visualized using Biovia Discovery Studio Visualizer V.20.1 and Schrodinger-Maestro V.12.7. The in silico studies were performed on a local machine equipped with AMD Ryzen 5 six-core $3.4 \mathrm{GHz}$ processor, 8 GB graphics and 16 GB RAM with Microsoft Windows 10 operating system.

\subsubsection{Computational studies}

Computational studies of synthesized compounds (3a-d) were conducted by using the Gaussian o9 software [43] with the help of the density functional theory at Becke-3-Lee-Yang-parr (DFT)/B3LYP level with $6-31 \mathrm{G}(\mathrm{d}, \mathrm{p})$ basis set [44]. The energy minimization process has been conducted at the same level in the gas phase to obtain a stable structure. The 3D representation of the optimized structure was presented in a molecular visualization program Gauss view 5.0 and the output was processed using the Avogadro software [45].

\section{Results and discussion}

\subsection{Chemistry}

In this report, we developed a convenient and straightforward method for the synthesis of 5-(3-substitutedthiophene)-pyrimidine derivatives (3a-d) via Knoevenagel condensation of barbituric/thiobarbituric acid (1) with 3-substituted-thiophene-2-carboxaldehyde (2) in aqueous ethanol using $\mathrm{H}_{2} \mathrm{O}_{2}: \mathrm{HCl}$ as catalyst (Scheme 1).

A possible mechanism for the formation of 5-(3-substituted-thiophene)-pyrimidine derivatives is shown in Scheme 2. Firstly, hypochlorous acid ( $\mathrm{HOCl}$ ) forms by the reaction of $\mathrm{H}_{2} \mathrm{O}_{2}$ with $\mathrm{HCl}$, and it acts as a 
powerful oxidizing agent. Then the reaction is initiated by the generation of carbanion $\mathbf{2}$ from active methylene compound 1. The carbanion 2 attacks the carbonyl carbon of aldehyde 3 to form intermediate 4 , which undergo subsequent dehydration to desired Knoevenagel product 5. $\mathrm{HOCl}$ increases the abstraction of acidic proton from active methylene compound and electrophilicity of carbonyl group of aldehydes due to hydrogen bonding.

Firstly, we studied the effect of catalyst on the reaction. In the previous reports, the same reaction was carried out in the presence of different catalysts such as $\mathrm{CuO}$ NPs, PVP-Ni NPs, $\mathrm{Fe}_{3} \mathrm{O}_{4}$ NPs, L-tyrosine, $\mathrm{NH}_{2} \mathrm{SO}_{3} \mathrm{H}, \mathrm{EAN}$, $\mathrm{Bi}\left(\mathrm{NO}_{3}\right)_{3} \cdot 5 \mathrm{H}_{2} \mathrm{O}$, and also in the absence of catalyst (Table 1). We studied the influence of catalyst in the progress of reaction as well as on the increased product yield. The results were not very encouraging. Therefore, we concluded that the best result was obtained in the presence of green halogenating catalyst $6 \% \mathrm{H}_{2} \mathrm{O}_{2}: \mathrm{HCl}$, where a further increase in the quantity of catalyst doesn't significantly affect reaction kinetics.

Consequently, to study the effect of temperature on synthesized compound $3 \mathrm{a}$, we carried out the reaction at room temperature, $50{ }^{\circ} \mathrm{C}$ and $80{ }^{\circ} \mathrm{C}$ (Table 2). As a result, an increase in the reaction temperature decreased the reaction time from 60 to 20 and 20 to $10 \mathrm{~min}$, respectively. Still, the yield of the product was not affected by an increase in temperature.

The structures of the intended 5-(3-substitutedthiophene)-pyrimidine derivatives (3a-d) were confirmed by IR, ${ }^{1} \mathrm{H}$ NMR, ${ }^{13} \mathrm{C}$ NMR and HRMS spectral data. IR spectrum of compound 3 a showed that the absorption band in the region $3373 \mathrm{~cm}^{-1}$ is attributed to the amide stretching vibration, and the absorption band at $1654 \mathrm{~cm}^{-1}$ corresponds to stretching vibration of the carbonyl group $(\mathrm{C}=\mathrm{O})$. Another stretching vibrational band at $1529 \mathrm{~cm}^{-1}$ corresponds to $\mathrm{C}=\mathrm{C}$ bond. The ${ }^{1} \mathrm{H}$ NMR spectrum of compound $3 a$ exhibited two singlet peaks at $\delta 11.21$ and 11.17 ppm, which corresponds to two $\mathrm{NH}$ protons of pyrimidine nucleus $(\mathrm{s}, 2 \mathrm{H}, \mathrm{NH})$ and another singlet peak at $\delta$ $8.53 \mathrm{ppm}$ due to $\mathrm{CH}$ proton $(\mathrm{s}, 1 \mathrm{H}, \mathrm{CH})$. A multiplet peak was observed in the range of $\delta 8.24-8.13 \mathrm{ppm}$, corresponds to two aromatic protons $(\mathrm{m}, 2 \mathrm{H}, \mathrm{Ar}-\mathrm{H})$ and a triplet peak at 7.33-7.31 ppm due to one aromatic proton $(t$, $J=8 \mathrm{~Hz}, 1 \mathrm{H}, \mathrm{Ar}-\mathrm{H})$.

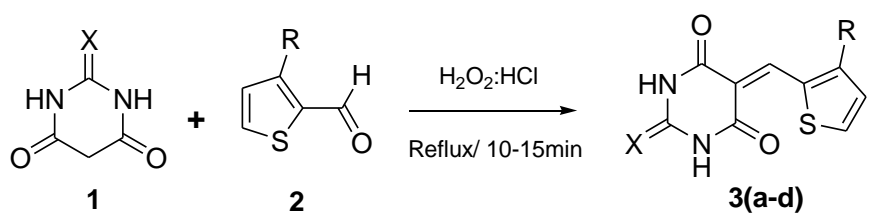

$\mathrm{X}=\mathrm{O} \& \mathrm{~S}, \mathrm{R}=\mathrm{H} \& \mathrm{CH}_{3}$

Scheme 1 Synthesis of 5-(3-substituted-thiophene)-pyrimidine derivatives (3a-d)

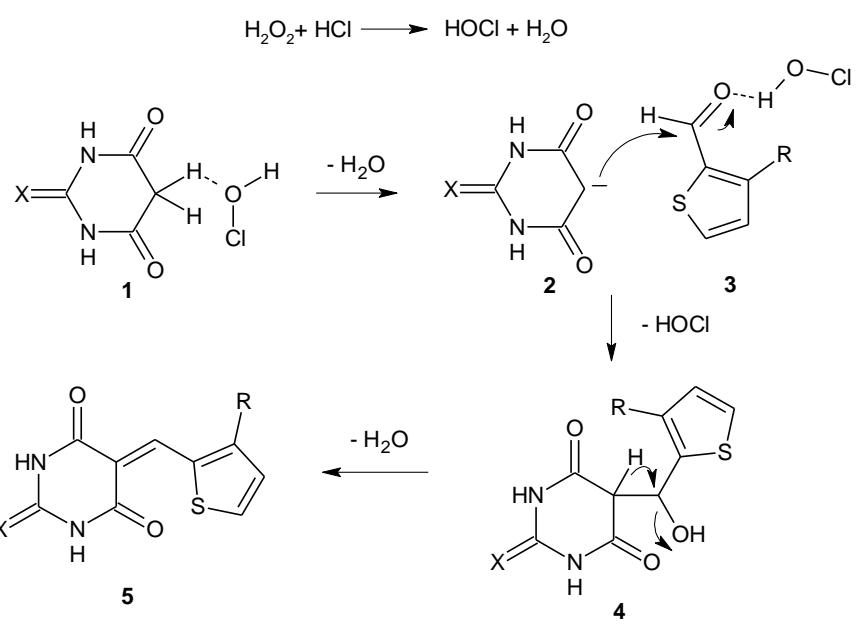

Scheme 2 Possible mechanism of synthesized compounds (3a-d)

In addition, the ${ }^{13} \mathrm{C}$ NMR spectrum of compound $3 \mathrm{a}$ exhibited peaks at $\delta 163.950$ and $163.453 \mathrm{ppm}$, which correspond to carbonyl carbons.

The mass spectrum showed molecular ion peak $[\mathrm{M}+\mathrm{H}]^{+}$ at $\mathrm{m} / \mathrm{z}$ is 221. 9054 corresponds to the molecular weight of compound $3 \mathbf{3}$ (Supporting information: S1 to S16). The physical and analytical data of synthesized compounds (3a-d) were appended in Table 3.

\subsection{Pharmacological effect}

\subsubsection{Antibacterial activity}

The synthesized 5-(3-substituted-thiophene)-pyrimidine derivatives (3a-d) were screened for their in vitro antibacterial activity at two different concentrations ( 20 and $40 \mu \mathrm{g} / \mathrm{mL}$ ). All four compounds showed appreciable antibacterial activity with a varied zone of inhibition in the range of 3.3 to 3.8 and 7.1 to $7.8 \mathrm{~mm}$ against $E$. coli and 3.0 to 3.7 and 7.4 to $7.9 \mathrm{~mm}$ against $S$. aureus, respectively (Table 4 ).

Table 1 Effect of catalysts on synthesized compound $\mathbf{3 a}$

\begin{tabular}{|c|c|c|c|c|c|}
\hline Entry & Catalyst & Solvent & Temperature, ${ }^{\circ} \mathrm{C}$ & Time, min & Yield, \% \\
\hline 1 & $\mathrm{H}_{2} \mathrm{O}_{2}: \mathrm{HCl}$ & EtOH: $\mathrm{H}_{2} \mathrm{O}$ & Reflux & 10 & 96 \\
\hline 2 & CuO NPs & - & RT & 10 & $93[46]$ \\
\hline 3 & PVP-Ni NPs & Ethylene glycol & Reflux & 10 & 87 [47] \\
\hline 4 & $\mathrm{Fe}_{3} \mathrm{O}_{4} \mathrm{NPs}$ & EtOH & Reflux & 30 & $70[48]$ \\
\hline 5 & L-tyrosine & $\mathrm{H}_{2} \mathrm{O}$ & RT & 16 & 93 [49] \\
\hline 6 & $\mathrm{NH}_{2} \mathrm{SO}_{3} \mathrm{H}$ & - & Grinding & 120 & $96[50]$ \\
\hline 7 & - & Ionic liquids & RT & 10 & $96[51]$ \\
\hline 8 & $\mathrm{Bi}\left(\mathrm{NO}_{3}\right)_{3} \cdot 5 \mathrm{H}_{2} \mathrm{O}$ & EtOH & Reflux & 20 & 95 [52] \\
\hline 9 & - & $\mathrm{EtOH}$ & Reflux & 120 & 89 [53] \\
\hline
\end{tabular}


Table 2 Effect of temperature on synthesized compounds $3 a$

\begin{tabular}{cccc}
\hline Entry & Temperature, ${ }^{\circ} \mathrm{C}$ & Time, min & Yield, $\%$ \\
\hline 1 & RT & 60 & 96 \\
\hline 2 & 50 & 20 & 96 \\
\hline 3 & 80 & 10 & 96 \\
\hline
\end{tabular}

The results revealed that compounds $3 \mathrm{~b}$ (3.8 and $7.8 \mathrm{~mm})$ and $3 \mathrm{~d}(3.7$ and $7.9 \mathrm{~mm})$ having electrondonating group (methyl) on $\mathrm{C}-3$ of the thiophene ring exhibited the most inhibitory effect against bacterial strains $E$. coli and $S$. aureus, respectively, compared to the standard drug Ciprofloxacin.

\subsubsection{Cytotoxicity}

All the four synthesized compounds were investigated for their in vitro cytotoxicity against $\mathrm{MCF}-7$ (Breast cancer) cell line (Fig. 2). The plot details compound concentration versus the survival fraction (Fig. 3). The percentages of cell survival of the tested compounds are listed in Table 5.

In vitro cytotoxicity results revealed that all four compounds displayed a superior selectivity against the MCF-7 cell line. Among the compounds tested, compound $3 \mathbf{a}$ exhibited promising cytotoxicity with a minimum cell survival range of 23.68 to $44.16 \%$ at the concentration range of 200 to $6.25 \mu \mathrm{g} / \mathrm{mL}$. Whereas $3 \mathrm{~b}, 3 \mathrm{c}$ and $3 \mathrm{~d}$ displayed reliable selectivity at all the concentrations with cell sur- vival ranges of 29.00 to $50.93 \%, 31.31$ to $66.82 \%$ and 26.95 to $53.12 \%$, respectively.

\subsubsection{DNA binding study}

DNA binding was assessed using electronic spectroscopy. The UV-absorption spectral studies were employed to examine the binding mode of compounds to CT DNA, which involves the changes in absorbance and wavelength [55]. The molecules are bound to DNA with two modes (covalent or noncovalent) of binding. The covalent binding led to bathochromism and hyperchromism due to breaking the DNA structure when a compound interacted with DNA covalently. While in non-covalent binding, there are "electrostatic", "groove", and "intercalative" types of interactions.

Table 4 Antibacterial activity results of synthesized compounds (3a-d)

\begin{tabular}{|c|c|c|c|c|}
\hline \multirow{4}{*}{ Compd. } & \multicolumn{4}{|c|}{ Zone of inhibition in $\mathrm{mm}$} \\
\hline & \multicolumn{2}{|c|}{ Escherichia coli } & \multicolumn{2}{|c|}{ Staphylococcus aureus } \\
\hline & \multicolumn{4}{|c|}{ Concentration in $\mu \mathrm{g} / \mathrm{mL}$} \\
\hline & 20 & 40 & 20 & 40 \\
\hline $3 a$ & 3.5 & 7.8 & 3.0 & 7.5 \\
\hline 3b & 3.8 & 7.8 & 3.1 & 7.6 \\
\hline 3c & $3 \cdot 3$ & 7.2 & $3 \cdot 5$ & $7 \cdot 4$ \\
\hline $3 d$ & 3.4 & 7.1 & 3.7 & $7 \cdot 9$ \\
\hline Ciprofloxacin & 4.0 & 8.0 & 4.2 & 8.4 \\
\hline
\end{tabular}

Table 3 Physical and analytical data of synthesized compounds (3a-d)

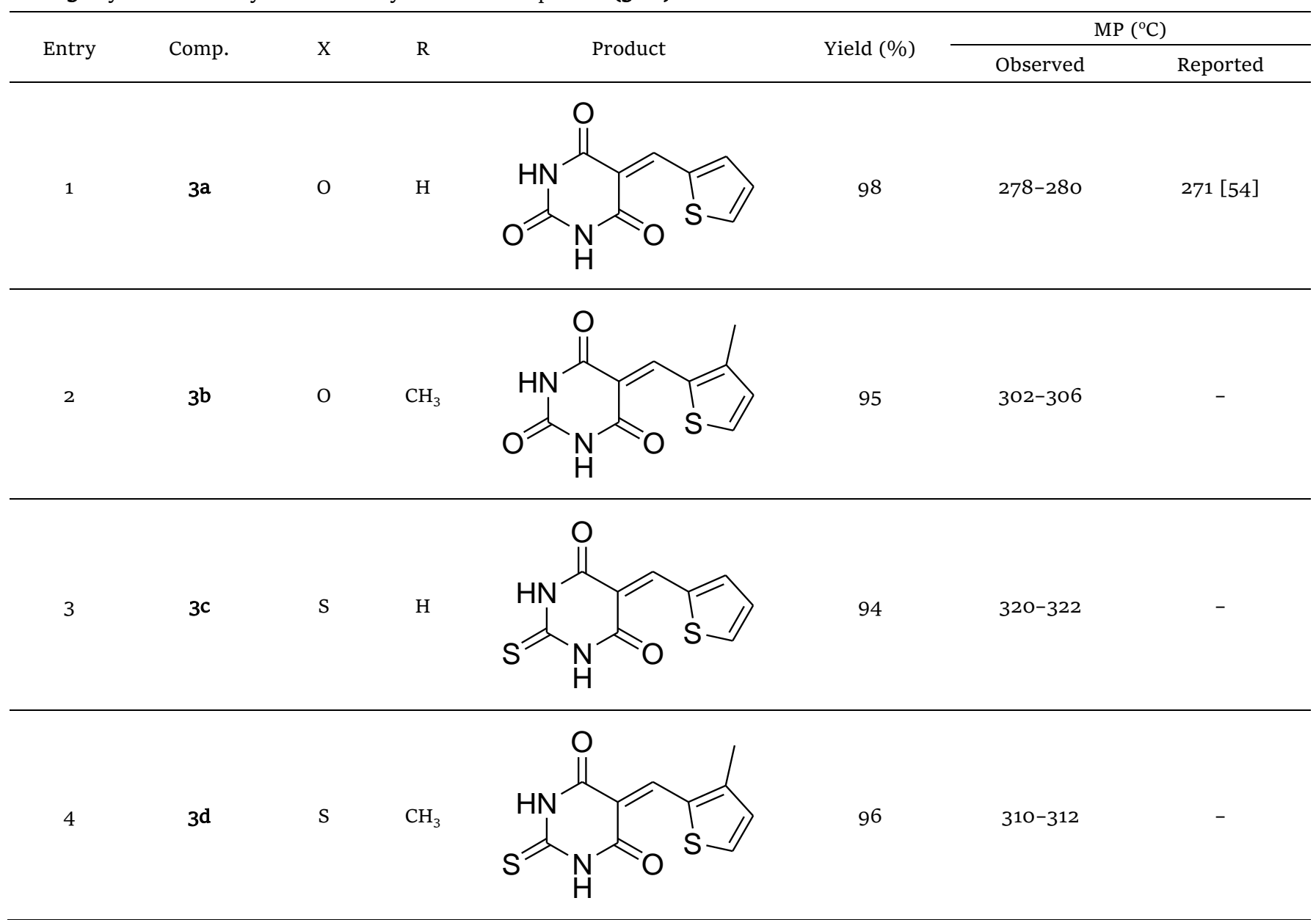



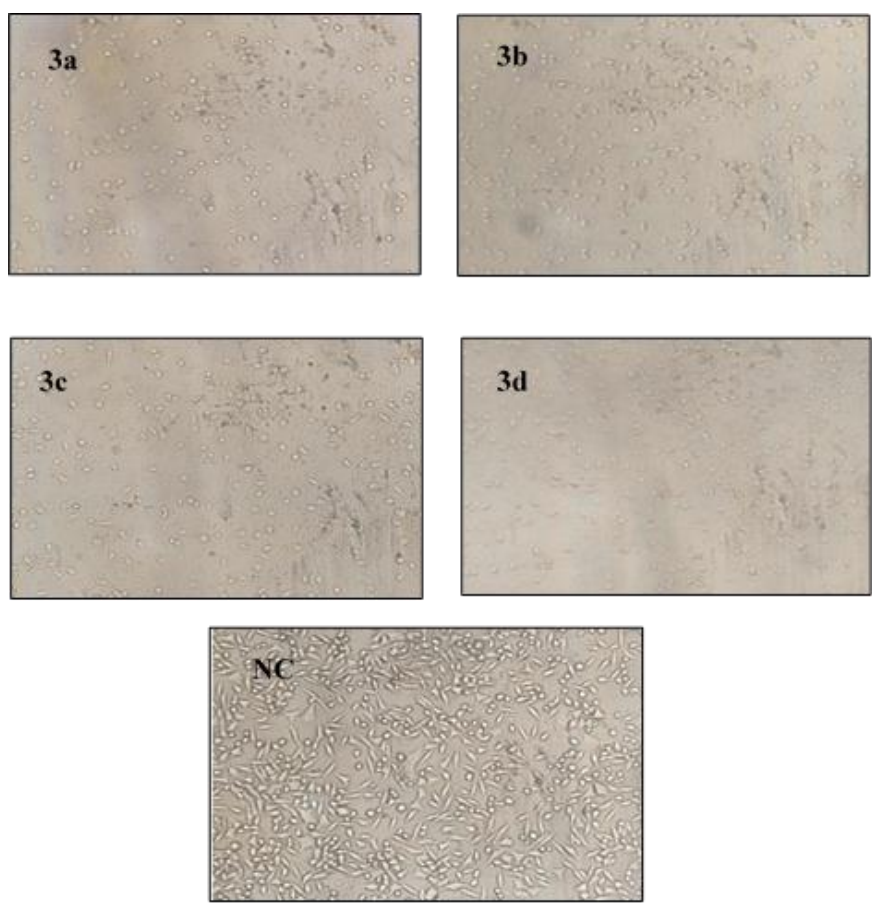

Fig. 2 Images of anticancer study of the synthesized compounds (3a-d)

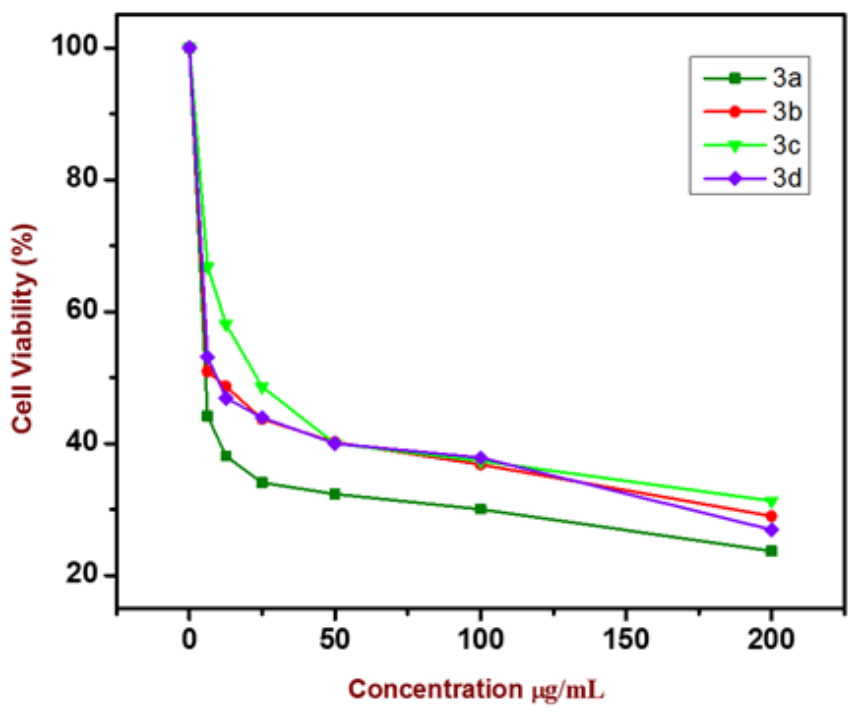

Fig. 3 A graph of $\%$ of surviving cells of compounds (3a-d) at different concentration against MCF-7 cell line

Table 5 Percentage of cell viability against MCF-7 cell line of the synthesized compounds (3a-d)

\begin{tabular}{ccccc}
\hline $\begin{array}{c}\text { Concent- } \\
\text { ration } \\
\text { in }\end{array}$ & 3a & 3b & $3 \mathrm{c}$ & 3d \\
\cline { 2 - 5 }$\mu \mathrm{g} / \mathrm{mL}$ & $44.16 \pm 0.76$ & $50.93 \pm 0.42$ & $66.82 \pm 0.41$ & $53.12 \pm 0.34$ \\
\hline 6.25 & $38.11 \pm 0.82$ & $48.68 \pm 0.31$ & $58.1 \pm 0.13$ & $46.88 \pm 0.52$ \\
\hline 12.5 & $34.09 \pm 1.2$ & $43.72 \pm 0.52$ & $48.6 \pm 0.23$ & $43.93 \pm 0.42$ \\
\hline 25 & $32.37 \pm 0.82$ & $40.23 \pm 0.61$ & $40.03 \pm 0.82$ & $40.03 \pm 0.62$ \\
\hline 50 & $30.06 \pm 0.62$ & $36.80 \pm 0.20$ & $37.38 \pm 0.61$ & $37.85 \pm 0.34$ \\
\hline 100 & $23.68 \pm 0.41$ & $29.00 \pm 0.16$ & $31.31 \pm 0.42$ & $26.95 \pm 0.52$ \\
\hline 200 & & &
\end{tabular}

Values are Mean $\pm \mathrm{SE}, \mathrm{N}=3,{ }^{\star} \mathrm{P}<0.01$ vs. Control
Decreased absorption (hypochromic shifts) and redshift (bathochromic shift) revealed the intercalative binding of compounds with DNA. Lower hypochromic/hyperchromic effect with no or negligible bathochromic shift led to the electrostatic binding. Minor or no effect and, rarely, some hyperchromism show the groove binding [56-58].

The DNA binding efficiency of synthesized compounds (3a-d) was monitored by comparing their absorption spectra with and without CT DNA. The absorption spectra were carried out at a fixed concentration of synthesized compounds and varying with DNA concentrations $(25-350 \mu \mathrm{L}$ of $0.5025 \cdot 10^{-7}$ to $6.0670 \cdot 10^{-7} \mathrm{~mol} \mathrm{~L}^{-1}$ ) under the physiological condition of $\mathrm{pH}$ 7.01. The absorption spectra of all the synthesized compounds (3a-d) exhibited absorption bands at 235 to $240 \mathrm{~nm}$ due to $\pi-\pi^{*}$ transitions (Fig. 4 ). The $K \mathrm{~b}$ values of compounds (3a-d) are found to be $1.1216 \cdot 10^{7}, 1.4072 \cdot 10^{7}$, $1.0634 \cdot 10^{7}$ and $3.4872 \cdot 10^{7}$ respectively are shown in Table 6. These $K_{\mathrm{b}}$ values confirm that all the synthesized compounds interacted strongly with CT DNA. Among the four compounds, compound 3d showed a prominent binding ability with CT DNA compared to other compounds. The absorption bands of the compounds were affected due to the gradual increase of CT DNA concentration resulting hyperchromism/hypochromism. No/or negligible blue/red shift indicates strong interaction of the compounds with CT DNA mainly through electrostatic or groove binding [59]. The kinetics and thermodynamics of compounds-DNA interaction in terms of binding constant $\left(K_{\mathrm{b}}\right)$ and Gibbs free energy change $(\Delta G)$ were evaluated using the classical Van't Hoff's equation, $\Delta G=-2.303 R T \log K \mathrm{~b}$. The negative $\Delta G$ values confirmed spontaneous binding of compounds with CT DNA through the formation of stable complexes.

\subsubsection{In silico ADME-toxicology studies}

The bioavailability and drug-likeness were estimated for all the synthesized compounds (3a-d) based on the molecular properties. The results indicated that all the four compounds under study could pass through Lipinski's filter without any violation, demonstrating a positive druglikeness score indicating their suitability as drug-leads. In silico pharmacokinetic studies showed that all the molecules under investigation could penetrate the blood-brain barrier and are readily absorbed by the human intestine while they are impermeable to Caco-2, and non-substrate Cytochromes P45O (CYP45O) group of enzymes (Table 7).

\begin{tabular}{ccccccc} 
Table 6 DNA binding results of synthesized compounds (3a-d) \\
\hline \multirow{2}{*}{ Compd. } & \multicolumn{2}{c}{$\lambda_{\max }, \mathrm{nm}$} & $\Delta \lambda_{\max }$, & $\% \mathrm{H}$ & $K_{\mathrm{b}}, \mathrm{M}^{-1}$ & $\begin{array}{c}\Delta G, \\
\mathrm{~kJ} / \mathrm{mol}\end{array}$ \\
\cline { 2 - 8 } & Free & Bound & $\mathrm{nm}$ & & & \\
\hline 3a & 240 & 239 & 1 & $6.1879 \cdot 10^{-4}$ & $1.1216 \cdot 10^{7}$ & -40.205 \\
\hline 3b & 236 & 236 & $\mathrm{o}$ & $6.0157 \cdot 10^{-4}$ & $1.4072 \cdot 10^{7}$ & -40.767 \\
\hline 3c & 239 & 239 & $\mathrm{o}$ & $1.1560 \cdot 10^{-3}$ & $1.0634 \cdot 10^{7}$ & -40.073 \\
\hline 3d & 236 & 236 & $\mathrm{o}$ & $1.2388 \cdot 10^{-3}$ & $3.4872 \cdot 10^{7}$ & -43.015 \\
\hline
\end{tabular}



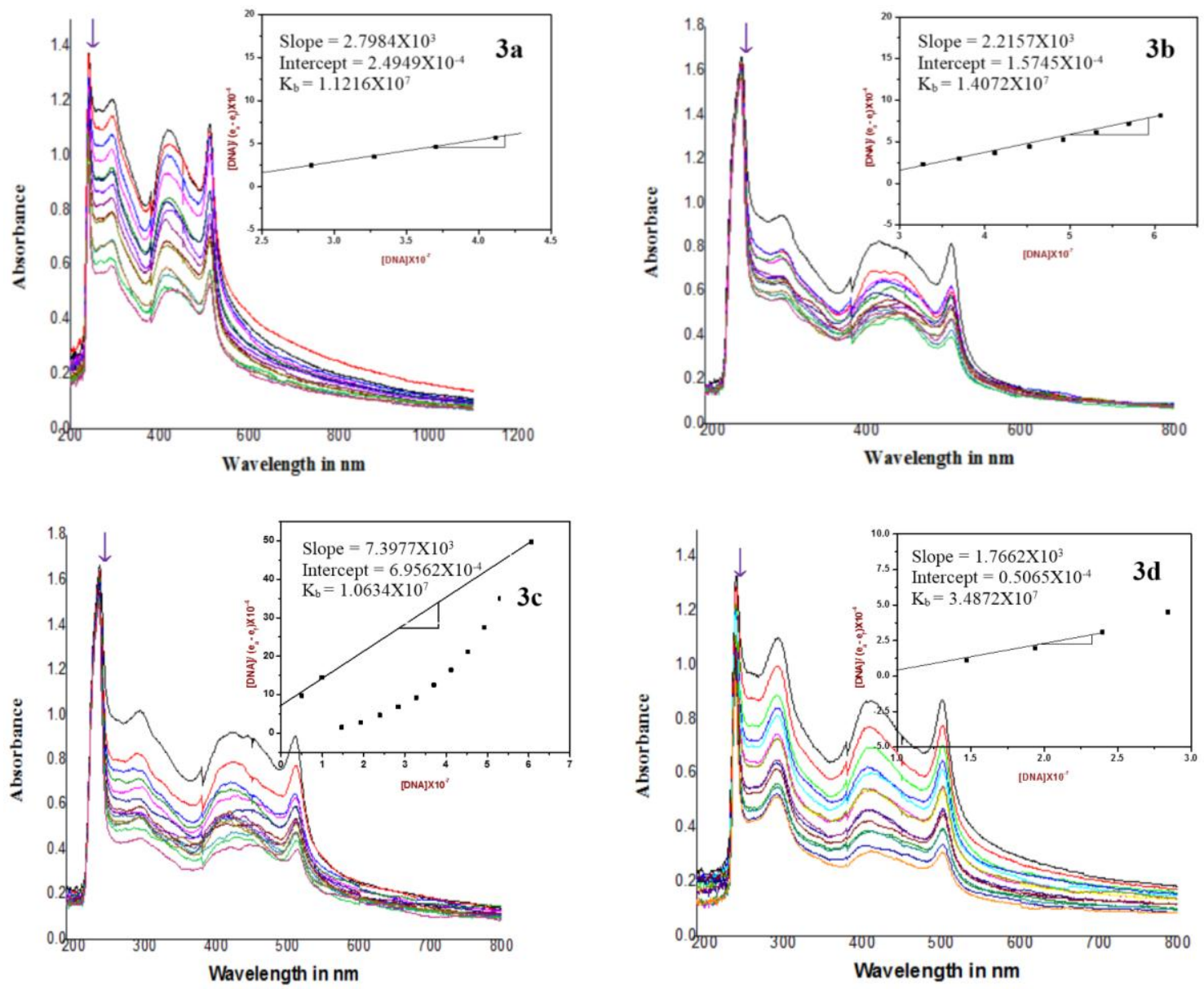

Fig. 4 The electronic absorption spectra of compounds (3a-d) in the absence and presence of increasing amounts of CT DNA. Arrow ( $\downarrow$ ) shows the change in the absorbance with increase the DNA concentration. Inset: plot of $[D N A] /\left(\in_{A}-\in_{F}\right)$ Vs [DNA]

Table 7 Bioavailability, drug likeness and in silico pharmacokinetic assessment of synthesized compounds (3a-d)

\begin{tabular}{|c|c|c|c|c|c|c|c|c|c|c|c|}
\hline \multirow[b]{2}{*}{ Comp. } & \multicolumn{7}{|c|}{ Bioavailability and Drug likeness } & \multicolumn{4}{|c|}{ In silico Pharmacokinetics } \\
\hline & 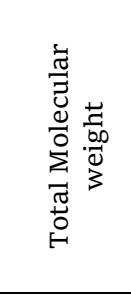 & $\begin{array}{l}\text { के } \\
\text { o } \\
\text { y }\end{array}$ & 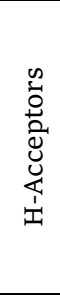 & $\begin{array}{l}\text { n } \\
0 \\
0 \\
0 \\
0 \\
\text { 1 } \\
\text { 离 }\end{array}$ & $\begin{array}{l}0 \\
0 \\
0 \\
\infty \\
0 \\
0 \\
\pi \\
\pi \\
0 \\
0\end{array}$ & 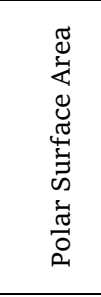 & 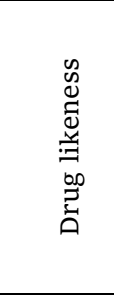 & 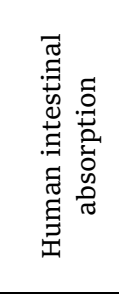 & 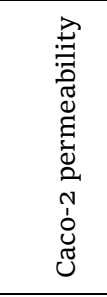 & 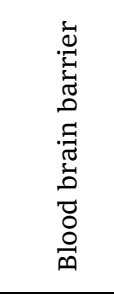 & 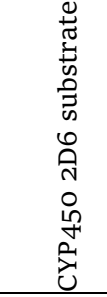 \\
\hline $3 a$ & 222.224 & 0.2739 & 5 & 2 & 1 & 103.51 & 5.2698 & +0.982 & -0.779 & +0.982 & -0.873 \\
\hline $3 b$ & 236.251 & 0.6178 & 5 & 2 & 1 & 103.51 & 4.9763 & +0.728 & -0.753 & +0.980 & -0.889 \\
\hline $3 c$ & 238.291 & 0.6344 & 4 & 2 & 1 & 118.53 & 4.2229 & +0.979 & -0.698 & +0.977 & -0.871 \\
\hline $3 d$ & 252.318 & 0.9783 & 4 & 2 & 1 & 118.53 & 3.9143 & +0.987 & -0.673 & +0.976 & -0.886 \\
\hline
\end{tabular}

In silico pharmacodynamics studies revealed that all the four molecules are non-mutagenic, nontumorigenic, non-irritant, AMES non-toxic with high reproductive effects with possible hepatotoxicity. The bioactivity assessment indicated that the molecules do not belong to the GPCR group of ligands, do not modulate ion channels, non-kinase inhibitors, non-nuclear receptor ligands, non-protease and non-enzyme inhibitors (Table 8).

\subsubsection{Structure-activity relationship (SAR) studies}

The evaluation of the antibacterial activity of the newly synthesized compounds (3a-d) revealed that the presence of electron-donating methyl group has a significant effect on enhancing their potency. The compounds $\mathbf{3 b}$ and $\mathbf{3 d}$ have a methyl group at $\mathrm{C}-3$ of the thiophene ring. This could have improved their cell permeability, which improved their activity profile compared to $3 \mathbf{a}$ and $\mathbf{3 c}$. The combination of heterocyclic rings like pyrimidine and thiophene is presumed to be the main reason for the profound cytotoxicity of the newly synthesized compounds (3a-d). Furthermore, the presence of the urea group in the pyrimidine ring could have significantly contributed to the superior cytotoxicity of $\mathbf{3 a}$ and $\mathbf{3} \mathbf{b}$ compared to other synthesized molecules. 


\subsubsection{In silico molecular docking studies}

The results revealed that compound $\mathbf{3} \mathbf{b}$ bound with GlcN6-P and P38 MAPk with a minimum binding energy of -7.9 and $-6.4 \mathrm{kcal} / \mathrm{mol}$, respectively. $3 \mathrm{a}, 3 \mathrm{~d}$ and $3 \mathrm{c}$ interacted with a binding energy of -7.6 and $-6.4,-7.4$ and -6.2 and -7.4 and -6.0 with GlcN-6-P and P38 MAPk targets, respectively. The interaction of all the molecules with GlcN6-P and P38 MAPk were compared with antibacterial agent Ciprofloxacin $(-7.7 \mathrm{kcal} / \mathrm{mol})$ and anticancer agent 5-fluorouracil ( $-4.7 \mathrm{kcal} / \mathrm{mol}$ ) (Table 9, Fig.5). The computational methods in drug discovery have gained enormous importance in modern drug research. They play a critical role in reducing the virtual chemical space in synthesizing, modifying, and screening chemical drugs against a specific disease target. Their effectiveness can be validated using microbial pathogens due to their simpler and clearer cellular understandings. Similarly, cell death modalities can also be studied using in vitro cell culture studies, particularly focusing on necrosis, apoptosis, necroptosis, autophagic cell death, etc. [42]. In the present study, in silico molecular docking studies were performed to predict the most effective binding among the synthesized molecules to appropriate targets [6o, 61]. The studied molecules showed remarkable binding interactions with the selected target proteins, supporting their remarkable antimicrobial and anticancer effects.

\subsubsection{DFT studies}

Frontier molecular orbitals (FMOs) containing the highest occupied molecular orbital (HOMO) and lowest unoccupied molecular orbital (LUMO), as well as the energy gap ( $\Delta E=E_{\mathrm{HOMO}}-E_{\mathrm{LUMO}}$ ) were considered to be very effective parameters in chemical quantum chemistry [62]. FMOs also delivered important information about chemical reactivity, biological activity and kinetic stability of the molecules [63]. The optimized HOMO and LUMO structures of synthesized compounds (3a-d) are shown in Fig. 6 and 7. The HOMO and LUMO of compounds were helpful in determining of various global reactivity parameters such as ionization energy ( $\left.I=-E_{\mathrm{HOMO}}\right)$, electron affinity $\left(A=-E_{\mathrm{LUMO}}\right)$, chemical hardness $(\eta=1 / 2(I-A))$, chemical softness $(\sigma=1 / \eta)$, electronegativity $(\chi=1 / 2(I+A))$, chemical potential $(\mu=-\chi)$, and electrophilicity index $\left(\omega=\mu^{2} / 2 \eta\right)$ helps to study about donor- acceptor interaction and intramolecular charge transfer (ICT) ability of synthesized compounds [64].

The calculated HOMO-LUMO energies and global reactivity parameters of the synthesized compounds (3a-d) are displayed in Table 10. A smaller HOMO-LUMO energy gap $(\Delta E)$ indicates a soft molecule, while a larger gap indicates a hard molecule. Lower energy gap, less ionization potential, electron affinity, chemical hardness, electronegativity, electrophilicity index values and more softness values indicate that a molecule is more chemically and biologically active with low kinetic stability [65].
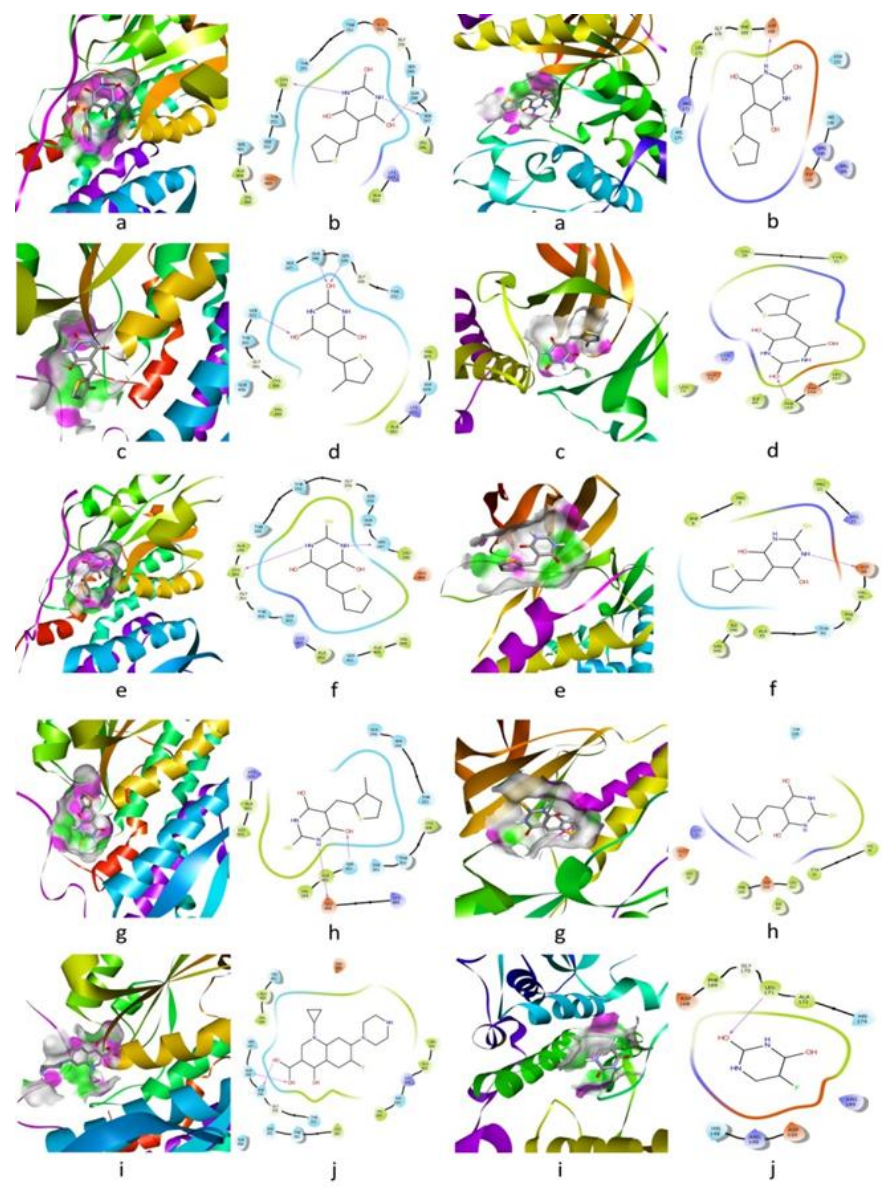

$\mathrm{f}$

Fig. 5 Binding interaction of compounds $\mathbf{3 a}$ ( $a$ and $b$ ), $\mathbf{3 b}$ (c and d), 3c (e and f), and $3 d$ ( $g$ and $h$ ) with GlcN-6-P along with standard drug ciprofloxacin ( $i$ and $j$ ) (a) and Binding interaction of compounds $3 a$ ( $a$ and $b$ ), $3 b$ (c and d), $3 c$ (e and f), and $3 d$ ( $g$ and $h$ ) with P38 MAPk along with standard drug 5-fluorouracil (I and j) (b)

Table 8 In silico pharmacodynamics and bioactivity assessment of synthesized compounds (3a-d)

\begin{tabular}{|c|c|c|c|c|c|c|c|c|c|c|c|c|c|}
\hline \multirow[b]{2}{*}{ Comp. } & \multicolumn{7}{|c|}{ In silico Pharmacodynamics } & \multicolumn{6}{|c|}{ Bioactivity score } \\
\hline & 岂 & 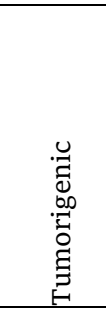 & 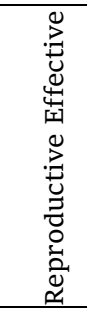 & 芯 & 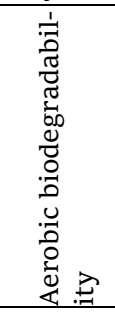 & 侌 & 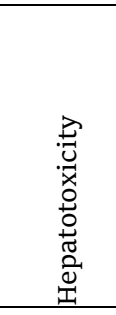 & 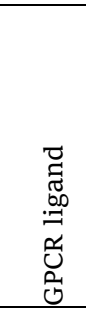 & 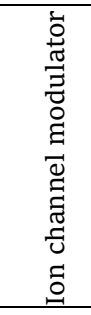 & 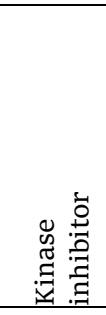 & 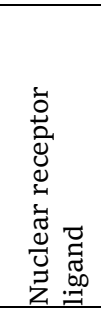 & 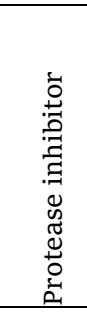 & : \\
\hline $3 a$ & NONE & NONE & $\mathrm{HIGH}$ & NONE & -0.590 & -0.706 & +0.925 & -1.12 & -1.58 & -0.86 & -1.26 & -1.30 & -0.69 \\
\hline $3 b$ & NONE & NONE & HIGH & NONE & -0.562 & -0.694 & +0.950 & -1.07 & -1.44 & -0.90 & -0.91 & -1.32 & -0.73 \\
\hline $3 c$ & HIGH & NONE & HIGH & NONE & -0.859 & -0.731 & +0.900 & -1.43 & -1.77 & -1.41 & -1.73 & -1.32 & -1.00 \\
\hline 3d & HIGH & NONE & HIGH & NONE & -0.843 & -0.711 & +0.850 & -1.35 & -1.62 & -1.42 & -1.35 & -1.34 & -1.03 \\
\hline
\end{tabular}


DFT studies data reveals that the energy gaps $(\Delta E)$ of compounds 3a, 3b, 3c and 3d are $0.16038 \mathrm{eV}, 0.15988 \mathrm{eV}$, $0.12799 \mathrm{eV}$ and $0.12636 \mathrm{eV}$, respectively. 3a, 3b and 3c, 3d moleculs show nearly similar energy gap due to the similar structure. Among them 3d molecule shows less energy gap $(0.12636 \mathrm{eV})$ and more softness value $(15.8277 \mathrm{eV})$; hence, it is chemically more reactive compared to the other molecules. $3 a$ molecule has more electronegative value $(0.19923 \mathrm{eV})$; hence, it has more tendency to attract a bonding electron pairs compared to the other molecules.

Table 9 Binding energies of synthesized compounds (3a-d) with GlcN-6-P and P38 MAPk targets

\begin{tabular}{cccc}
\hline \multicolumn{2}{c}{ Antibacterial activity } & \multicolumn{2}{c}{ Anticancer activity } \\
\hline Compd. & $\begin{array}{c}\text { Binding } \\
\text { energy in } \\
\text { kcal/mol }\end{array}$ & Compd. & $\begin{array}{c}\text { Binding } \\
\text { energy in } \\
\text { kcal/mol }\end{array}$ \\
\hline Ciprofloxacin & -7.7 & 5-Fluorouracil & -4.7 \\
\hline 3a & -7.6 & 3a & -6.4 \\
\hline 3b & -7.9 & 3b & -6.4 \\
\hline 3c & -7.4 & 3c & -6.0 \\
\hline 3d & -7.4 & 3d & -6.2 \\
\hline
\end{tabular}

\section{Conclusions}

We described a mild, easy and green protocol for synthesizing 5-(3-substituted-thiophene)-pyrimidine derivatives (3ad) using $\mathrm{H}_{2} \mathrm{O}_{2}: \mathrm{HCl}$ as a catalyst under reflux condition. This synthetic approach has a short reaction time, excellent yield, and clean reactions make this procedure a magnificent alternative to the existing methods. Furthermore, this method is environmentally greener and safer. The activity results revealed that the compounds $3 \mathrm{~b}$ and $\mathbf{3 d}$ exhibited more potent antibacterial activity against $E$. coli and $S$. aureus than the standard drug Ciprofloxacin. In vitro cytotoxicity results disclosed the outstanding selectivity on MCF-7 cell line, mainly compound 3 a exhibiting the most effective cytotoxicity with a minimum cell survival range of 23.68 to $44.16 \%$. DNA binding results indicated that all the synthesized compounds interacted strongly with CT DNA, and compound-DNA complexes were stabilized by electrostatic or groove binding. In silico ADME-toxicology results showed that all the four compounds are non-toxic and suitable for oral bioavailability and drug-likeness, indicating their suitability as drug-leads.

Table 10 Chemical parameters of synthesized compounds (3a-d)

\begin{tabular}{ccccccccccccc}
\hline Entry & $\begin{array}{c}E_{\text {номо }} \\
(\mathrm{eV})\end{array}$ & $\begin{array}{c}E_{\mathrm{LUmo}}, \\
\mathrm{eV}\end{array}$ & $\begin{array}{c}\Delta E \\
E_{\text {Hомо }} \\
E_{\mathrm{LUMO}}, \mathrm{eV}\end{array}$ & $I, \mathrm{eV}$ & $A, \mathrm{eV}$ & $\eta, \mathrm{eV}$ & $\sigma, \mathrm{eV}$ & $\chi, \mathrm{eV}$ & $\mu, \mathrm{eV}$ & $\begin{array}{c}\omega, \mathrm{eV} \\
\mathrm{Debye}\end{array}$ \\
\hline 3a & -0.27942 & -0.11904 & 0.16038 & 0.27942 & 0.11904 & 0.08019 & 12.4703 & 0.19923 & -0.19923 & 0.24749 & 4.6744 \\
\hline 3b & -0.27411 & -0.11423 & 0.15988 & 0.27411 & 0.11423 & 0.07994 & 12.5093 & 0.19417 & -0.19417 & 0.23581 & 5.2238 \\
\hline 3c & -0.25095 & -0.12296 & 0.12799 & 0.25095 & 0.12296 & 0.06399 & 15.6274 & 0.18695 & -0.18695 & 0.27310 & 5.4300 \\
\hline 3d & -0.24793 & -0.12157 & 0.12636 & 0.24793 & 0.12157 & 0.06318 & 15.8277 & 0.18475 & -0.18475 & 0.27012 & 5.9267 \\
\hline
\end{tabular}
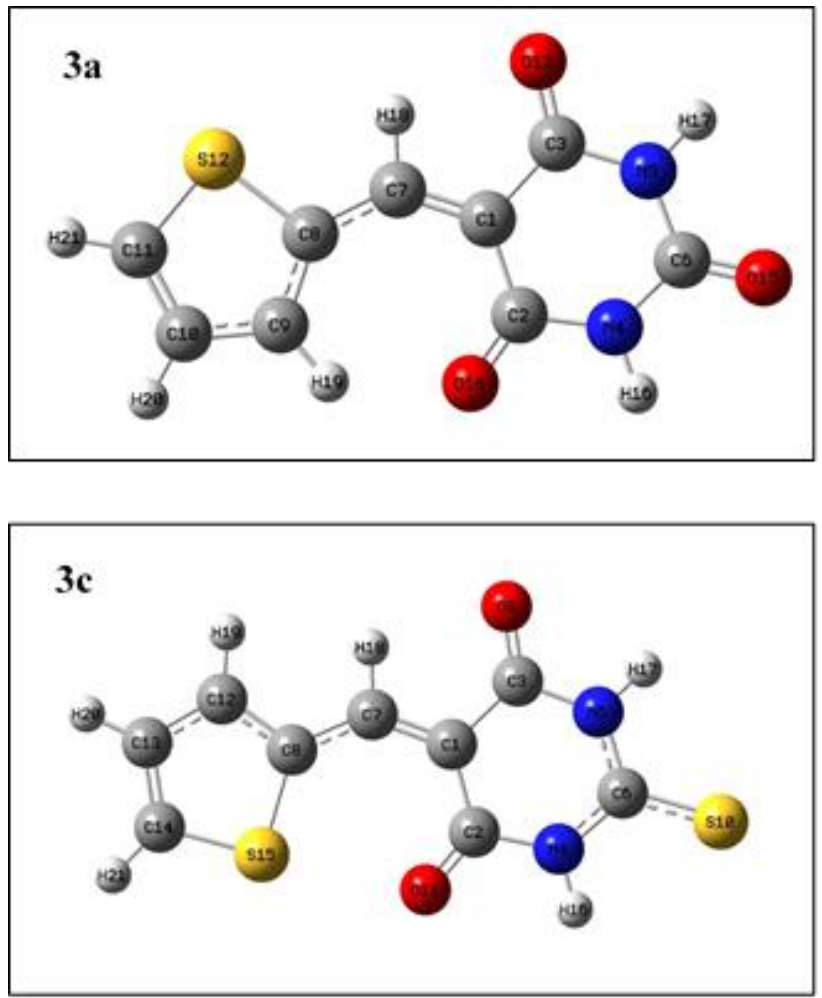

Fig. 6 Optimized structures of synthesized compounds (3a-d)
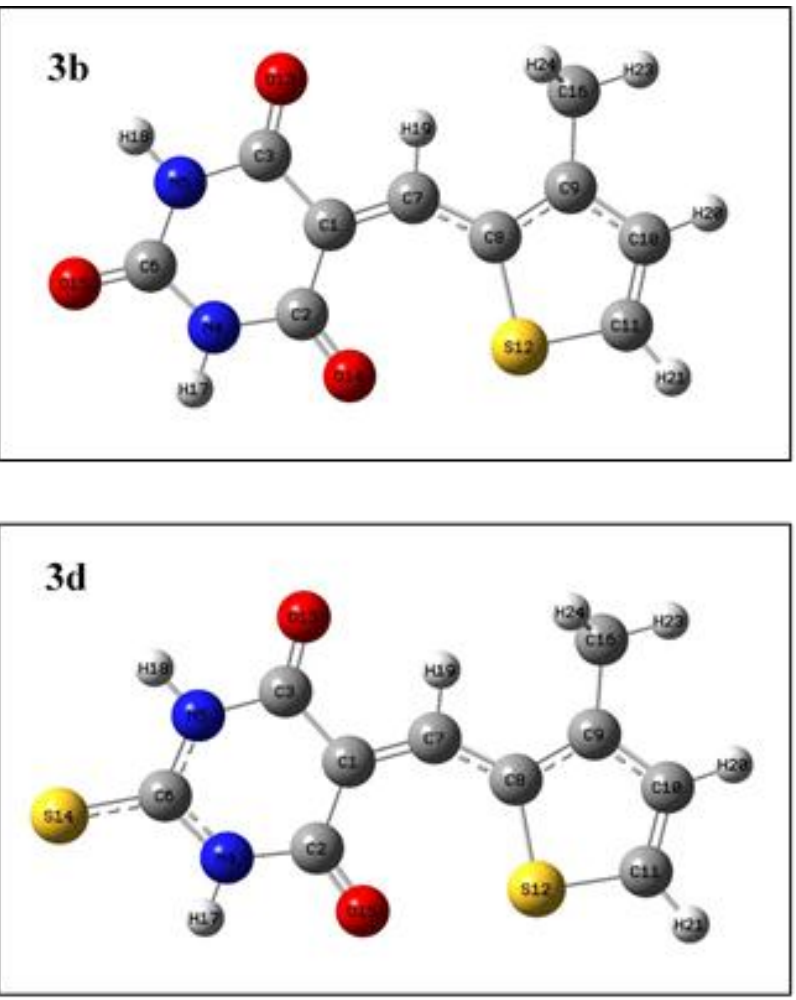


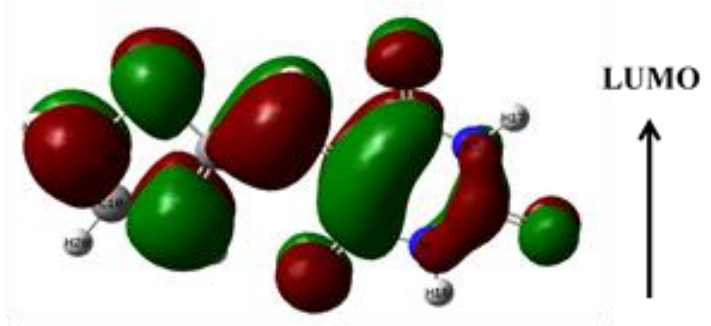

$\triangle E=0.16038 \mathrm{eV}$

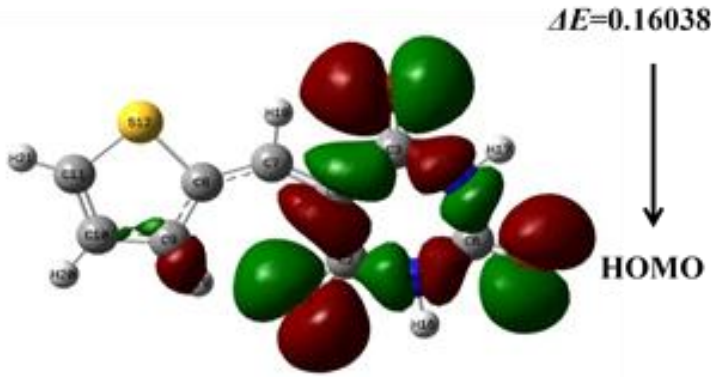

3a
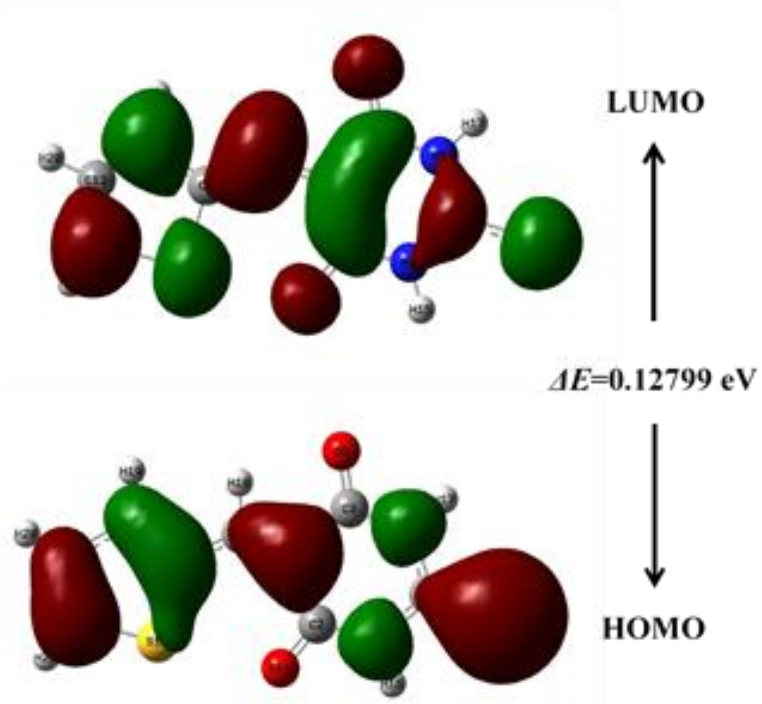

$3 c$

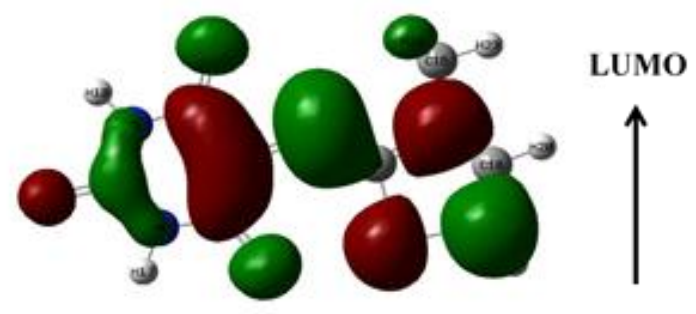

$\Delta E=0.15988 \mathrm{eV}$

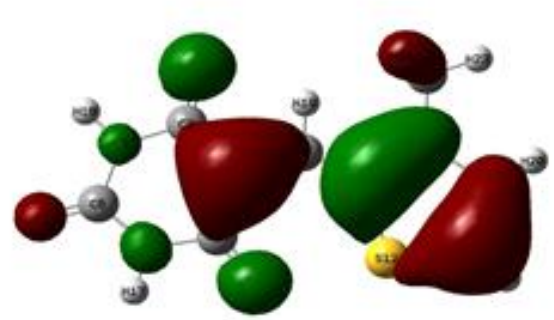

$3 b$
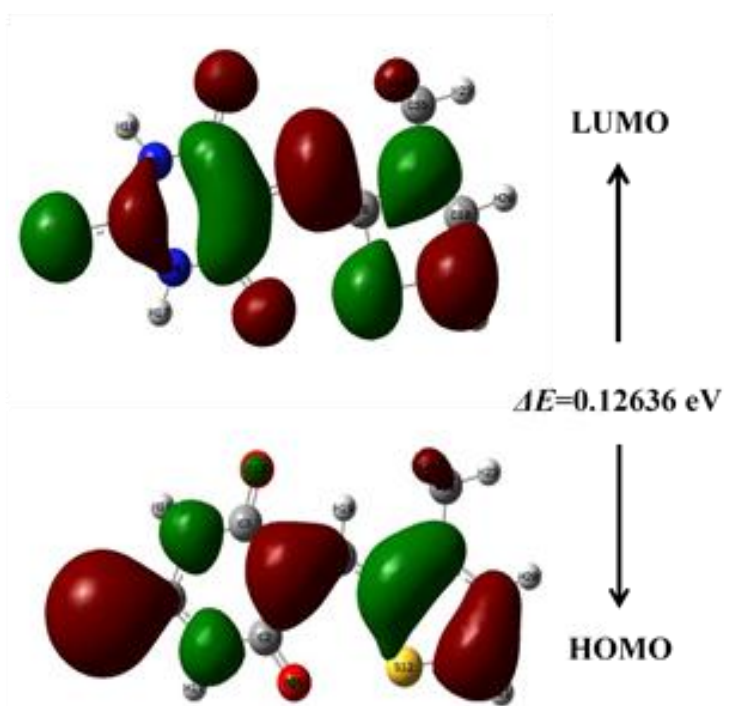

3d

Fig. 7 DFT study of synthesized compounds (3a-d)

In silico molecular docking results showed compound $3 \mathrm{~b}$ bound with GlcN-6-P and P38 MAPk with a least binding energy of -7.9 and $-6.4 \mathrm{kcal} / \mathrm{mol}$, respectively. DFT study result revealed that the compound $3 \mathrm{~d}$ was chemically and biologically more reactive with low kinetic stability due to less energy gap. In future, the obtained compounds can be used as antibiotics, anticancer agents, dyes and pigments in compounds as food industries.

\section{Acknowledgements}

The authors are thankful to the Chairman, Department of Chemistry, Kuvempu University, Shankaraghatta, for providing the laboratory facilities and SAIF, Mysore University, for providing the spectral data.

\section{Supporting information}

Spectroscopic spectra's (IR, ${ }^{1} \mathrm{HNMR},{ }^{13} \mathrm{CNMR}$ and HRMS) of the synthesized compounds are provided in the supporting information file.

\section{Conflict of Interest}

The authors declare that there is no conflict of interests regarding the publication of this work.

\section{References}

1. Singh PK, Silakari O. The current status of O-heterocycles: A synthetic and medicinal overview. Med Chem. 2018;13:10711087. doi:10.1002/cmdc.201800119

2. Pathania S, Narang RK, Rawal RK. Role of sulphurheterocycles in medicinal chemistry: An update. Eur J Med Chem. 2019;180:486-508. doi:10.1016/j.ejmech.2019.07.043 
3. Venkatesh T, Bodke YD, Manjunatha B, Kumar SR. Synthesis, antitubercular activity and molecular docking study of substituted $[1,3]$ dioxino[ $4,5-\mathrm{d}]$ pyrimidine derivatives via facile CAN catalyzed Biginelli reaction. Nucleosides, Nucleotides and Nucleic Acids. 2021:1-13. doi:10.1080/15257770.2021.1972310

4. Sravanthi B, Kaviarasan L, Praveen TK, Sai Kiran PSS, Pavankumar C, Gowramma B. Synthesis and pharmacological evaluation of 1,3,4-thiadiazole bearing pyrimidine derivatives as STAT3 inhibitor for treatment of breast cancer. J Iran Chem Soc. 2020;17:2359-2370. doi:10.1007/s13738-020-01932-Z

5. Kang D, Feng D, Ginex T, Zou J, Wei F, Zhao T, Huang B, Sun Y, Desta S, Clercq ED, Pannecouque C, Zhan P, Liu X. Exploring the hydrophobic channel of NNIBP leads to the discovery of novel piperidinesubstituted thiophene[3,2-d]pyrimidine derivatives as potent HIV-1 NNRTIs. Acta Pharm Sin B. 2020;10:878-894. doi:10.1016/j.apsb.2019.08.013

6. Prasad P, Anirudhdha GK and Patel MP. Microwave assisted one-pot synthetic route to imidazo[1,2-a]pyrimidine derivatives of imidazo/triazole clubbed pyrazole and their pharmacological screening. New J Chem. 2018;42:12666-12676. doi:10.1039/C8NJ00670A

7. Zia UHK, Arif UK, Pingyu W, Yongmei C, Dandan K, Shafiullah K, Kamran T. In vitro pharmacological screening of three newly synthesised pyrimidine derivatives. Nat Prod Res. 2015;29:933-938. doi:10.1080/14786419.2014.964707

8. Ghada SM. New Potential Antitumor Pyrimidine Derivatives: Synthesis and Cytotoxicity Evaluation. Polycycl Aromat Compd. 2021:1-17. doi:10.1080/10406638.2021.1936086

9. Zhen X, Cilong C, Lingjia Z, Zhihui Z, Qian Z, Feiyi Y, Zunhua Y, Pengwu Z, Shan X, Wufu Z. Discovery of thiapyranpyrimidine derivatives as potential EGFR inhibitors. Bioorg Med Chem. 2020;28:1-13. doi:10.1016/j.bmc.2020.115669

10. Zhen X, Zhihui Z, Cilong C, Qian Z, Lingjia Z, Zunhua Y, Xin Li, Liying Yu, Pengwu Z, Shan Xu, Wufu Z. Design, synthesis and antitumor activity of novel thiophene-pyrimidine derivatives as EGFR inhibitors overcoming T79oM and L858R/T79oM mutations. Eur J Med Chem. 2020;203:1-43. doi:10.1016/j.ejmech.2020.112511

11. Elshaymaa IE. Thieno[2,3-d]pyrimidine derivatives: Synthetic approaches and their FLT3 kinase inhibition. J Heterocyclic Chem. 2020;57:2067-2078. doi:10.1002/jhet.3934

12. Khalil NA, Ahmed EM, Zaher AF, El-Zoghbi MS, Sobh EA. Synthesis of certain benzothieno[3,2-d]pyrimidine derivatives as a selective SIRT2 inhibitors. Eur J Med Chem. 2020;187:1-56. doi:10.1016/j.ejmech.2019.111926

13. Shipilovskikh SA, Rubtsov AE. One-Pot Synthesis of Thieno[3,2-e]pyrrolo[1,2-a]pyrimidine Derivative Scaffold: A Valuable Source of PARP-1 Inhibitors. J Org Chem. 2019;84:15788-15796. doi:10.1021/acs.joc.9boo711

14. Lei S, Chengjuan C, Xueting H, Hao H, Manman W, Jianqiu Z, Yile Y, Jianming L, Tiantai Z, Dayong Z. Design, synthesis, and pharmacological evaluation of 4- or 6-phenylpyrimidine derivatives as novel and selective Janus kinase 3 inhibitors. Eur J Med Chem. 2020;191:1-18. doi:10.1016/j.ejmech.2020.112148

15. Giuseppe R, Loredana S, Valeria P, Marialuisa C, Sebastiano I, Emanuele A, Mario S, Alfredo C, Antonio R, Giuseppe F, Maria NM. [1]Benzothieno[3,2-d]pyrimidine derivatives as ligands for the serotonergic 5-HT7 receptor. Eur J Med Chem. 2019;183:1-16. doi:10.1016/j.ejmech.2019.111690

16. Ali I, Wani WA, Saleem K, Hsieh MF. Anticancer metallodrugs of glutamic acid sulphonamides: in silico, DNA binding, hemolysis and anticancer studies. RSC Adv. 2014;4:2962929641. doi:10.1039/C4RA02570A

17. Aarti A, Archana K, Dr. Amarjit KA, Dr. Nithish C, Yudhvir S. Recent advances made on anticancer drugs the therapeutic potential of the aromatic heterocyclic compounds. Int J Pharm Sci Rev Res. 2019;58:104-113.

18. Jawaid A, Ahsan AK, Zulphikar Ali, Rafi H, Shahar YM. Structure-activity relationship (SAR) study and design strategies of nitrogen-containing heterocyclic moieties for their anticancer activities. Eur J Med Chem. 2017;125:143-189. doi:10.1016/j.ejmech.2016.09.023

19. Prabodh CS, Kushal KB, Archana S, Diksha S, Aakash D. Thiazole-containing compounds as therapeutic targets for cancer therapy. Eur J Med Chem. 2020;188:1-47. doi:10.1016/j.ejmech.2019.112016

20. Garima M, Sumitra N, Pramod KS. Cancer: An overview. J Cancer Res. 2015;8:1-9. doi:10.5829/idosi.ajcr.2015.8.1.9336

21. Nathan MR and Schmid P. A review of fulvestrant in breast cancer. Oncol Ther. 2017;5:17-29. doi:10.1007/s40487-017-0046-2

22. Akhtar J, Khan AA, Ali Z, Haider R, Yar MS. Structure-activity relationship (SAR) study and design strategies of nitrogen containing heterocyclic moieties for their anticancer activities. Eur J Med Chem. 2016;125:143-189.

doi:10.1016/ j.ejmech.2016.09.023

23. Koohshari M, Dabiri M, Salehi P. Catalyst-free domino reaction in water/ethanol: an efficient, regio- and chemoselective one-pot multi-component synthesis of pyranopyrazole derivatives. RSC Adv. 2014;4:10669-10671. doi:10.1039/C3RA47639A

24. Daniel RB, De Visser SP, Shaik S, Neumann R. Electrophilic aromatic chlorination and haloperoxidation of chloride catalyzed by polyfluorinated alcohols: a new manifestation of template catalysis. J Am Chem Soc. 2003;125:12116-12117. doi:10.1021/ja0364524

25. Venkatesh T, Bodke YD, Nagaraj K, Kumar SR. One-pot synthesis of novel substituted phenyl-1,5-dihydro-2hbenzo[4,5] thiazolo[3,2-a]pyrimido[4,5-d]pyrimidine derivatives as potent antimicrobial agents. Med Chem. 2018;8:1-7 doi:10.4172/2161-0444.1000488

26. Venkatesh T, Bodke YD, Kenchappa R, Telkar S. Synthesis, antimicrobial and antioxidant activity of chalcone derivatives containing thiobarbitone nucleus. Med Chem. 2016;6:440448. doi:10.4172/2161-0444.1000383

27. Sukanya SH, Venkatesh $\mathrm{T}$, Kumar SR, Bodke YD. Facile $\mathrm{TiO}_{2}$ NPs catalysed synthesis of substituted-4-Hydroxy/methoxy benzylidene derivatives as potent antioxidant and antitubercular agents. Chem Data Collect. 2021;33:1-16. doi:10.1016/j.cdc.2021.100713

28. Venkatesh T, Bodke YD, Joy NM, Vinoda BM, Shiralgi Y, Dhananjaya BL. Synthesis of some novel 5,7-disubstituted-2phenyl-5H-[1,3,4]thiadiazolo[3,2-a]pyrimidine derivatives and evaluation of their biological activity. Lett Org Chem. 2016;13:661-671. doi:10.2174/1570178613666161017123123

29. Sukanya SH, Venkatesh T, Aditya Rao SJ, Joy MN. Efficient LProline catalyzed synthesis of some new (4-substitutedphenyl)-1,5-dihydro-2H-pyrimido[4,5-d][1,3]thiazolo[3,2a]pyrimidine-2,4(3H)-diones bearing thiazolopyrimidine derivatives and evaluation of their pharmacological activities. J Mol Struct. 2021;1247:1-13. doi:10.1016/j.molstruc.2021.131324

30. Shivakumara N, Murali Krishna P. Synthesis, Spectral Characterization, and Evaluation of their DNA interactions. Curr Chem Lett. 2019;8:157-168. doi:10.5267/j.ccl.2019.004.004

31. Ali I, Mukhtar SD, Hsieh MF, Alothman ZA, Alwarthan A. Facile synthesis of indole heterocyclic compounds based micellarnano anticancer drugs. RSC Adv. 2018;8:37905-37914. doi:10.1039/c8rao7060a

32. Wolfe A, Shimer GH, Meehan T. Polycyclic aromatic hydrocarbons physically intercalate into duplex regions of denatured DNA. Biochemistry. 1987;26:6392-6396.

33. Lipinski CA, Lombardo F, Dominy BW, Feeney PJ. Experimental and computational approaches to estimate solubility and permeability in drug discovery and development settings. Adv Drug Deliv Rev. 1997;23:3-25. doi:10.1016/So169-409X(96)00423-1

34. Aditya R, Venugopal T, Jayanna N, Paramesha M, Ramesh C. Bioactive isolates of Morus species as antibacterial agents and their insilico profiling. Lett. Drug Des Discov. 2020;17:19. doi:10.2174/1570180817999201104120815 
35. Jarrahpour A, Motamedifar M, Zarei M, Youssoufi MH, Mimouni M, Chohan ZH. Petra, Osiris, and Molinspiration together as a guide in drug design: Predictions and correlation structure/antibacterial activity relationships of new nsulfonyl monocyclic $\beta$-Lactams. Phosphorus Sulfur Silicon Relat Elem. 2010;185:491-497. doi:10.1080/10426500902953953

36. Raghavendra S, Aditya Rao SJ, Kumar V, Ramesh CK. Multiple ligand simultaneous docking (MLSD): A novel approach to study the effect of inhibitors on substrate binding to PPO. Comput Biol Chem. 2015;59:81-86. doi:10.1016/j.compbiolchem.2015.09.008

37. Sander T, Freyss J, Von Korff M, Rufener C. DataWarrior: An open-source program for chemistry aware data visualization and analysis. J Chem Inf Model 2015;55:460-473. doi:10.1021/ci500588j

38. Venkatesh T, Bodke YD, Aditya Rao SJ. Facile CAN catalyzed one pot synthesis of novel indol-5,8-pyrimido[4,5-

d]pyrimidine derivatives and their pharmacological study. Chem Data Collect. 2020;25:1-13. doi:10.1016/j.cdc.2019.100335

39. Cheng F, Li W, Zhou Y, Shen J, Wu Z, Liu G. AdmetSAR. A comprehensive source and free tool for assessment of chemical ADMET properties. J Chem Inf Model. 2012;52:30993105. doi:10.1021/ci300367a

40. Trott O, Olson JA. AutoDockVina: Improving the speed and accuracy of docking with a new scoring function, efficient optimization and multithreading. J Comput Chem. 2010;31:455461. doi:10.1002/jcc.21334

41. Aditya Rao SJ, Ramesh CK, Raghavendra S, Paramesha M. Dehydroabietylamine, A diterpene from carthamus tinctorious $L$. showing antibacterial and anthelmintic effects with computational evidence. Curr Comput Aided Drug Des. 2020;16:231-237. doi:10.2174/1573409915666190301142811

42. Aditya Rao SJ, Shivayogi SM, Satyanarayana JK, Kumaran RC. Characterization of isolated compounds from Morus spp. and their biological activity as anticancer molecules. Bioimpacts 2021;11:1-11. doi:10.34172/bi.2021.09

43. Frisch MJEA, Trucks GW, Schlegel HB, Scuseria GE, Robb MA, Cheeseman JR, Nakatsuji H. Gaussian 09, Revision d. 01, Gaussian. Inc. Wallingford CT 2009;201.

44. Becke AD. A new mixing of Hartree-Fock and local densityfunctional theories. J Chem Phys. 1993;98:1372-1377.

45. Hanwell MD, Curtis DE, Lonie DC, Vandermeersch T, Zurek E Hutchison GR. Avogadro an advanced semantic chemical editor, visualization, and analysis platform. Aust J Chem. 2012;4:1-33. doi:10.1186/1758-2946-4-17

46. Dighore NR, Anandgaonker PL, Gaikwad ST, Rajbhoj AS. Solvent free green synthesis of 5 -arylidine barbituric acid derivatives catalyzed by copper oxide nanoparticles. Res J Chem Sci. 2014;4:93-98.

47. Khurana JM, Kanika Vij. Nickel nanoparticles catalyzed knoevenagel condensation of aromatic aldehydes with barbituric acids and 2-thiobarbituric acids. Catal Lett. 2010;138:104-110. doi:10.1007/s10562-010-0376-2

48. Fattahi M, Davoodnia A, Pordel M. Efficient one-pot synthesis of some new pyrimido[5,4:5,6]pyrido[2,3-d]pyrimidines catalyzed by magnetically recyclable $\mathrm{Fe}_{3} \mathrm{O}_{4}$ nanoparticles. Russ J Gen Chem. 2017;87:863-867. doi:10.1134/S1070363217040326

49. Thirupathi G, Venkatanarayana M, Dubey PK, BharathiKumari Y. Facile and green syntheses of 5 -arylidene-pyrimidine2,4,6-triones and 5-arylidene-2-thioxo-dihydro-pyrimidine-4, 6 -diones using L-tyrosine as an efficient and eco-friendly catalyst in aqueous medium. Chem Sci Trans. 2013;2:441-446. doi: $10.7598 /$ cst2013.385

50. Tai Li J, Guang Dai H, Liu D, Shuang Li T. Efficient method for synthesis of the derivatives of 5-arylidene barbituric acid catalyzed by aminosulfonic acid with grinding. Synth Commun. 2006;36:789-794. doi:10.1080/00397910500451324
51. Hu Y, Chen ZC, Le ZG, Zheng QG. Organic reactions in ionic liquids: ionic liquid promoted knoevenagel condensation of aromatic aldehydes with (2-thio) barbituric acid. Synth Commun. 2004;34:4521-4529. doi:10.1081/SCC-200043210

52. Shabeer M, Barbosa LCA, Karak M, Coelho ACS. Thiobarbiturates as potential antifungal agents to control human infections caused by Candida and Cryptococcus species. Med Chem Res. 2018;27:1043-1049. doi:10.1007/s00044-017-2126-O

53. Yan Q, Cao R, Yi W, Chen Z, Wen H, Ma L, Song H. Inhibitory effects of 5-benzylidene barbiturate derivatives on mushroom tyrosinase and their antibacterial activities. Eur J Med Chem. 2009;44:4235-4243. doi:10.1016/j.ejmech.2009.05.023

54. Egorova S, Ivanova VN, Putokhin NI. Thiophene aldehyde and its derivatives. Chem Heterocycl Comp. 1967;3:654. doi:10.1007/BF00468337

55. Ramesh G, Daravath S, Ganji N, Rambabu A, Venkateswarlu K. Facile synthesis, structural characterization, DNA binding, incision evaluation, antioxidant and antimicrobial activity studies of Cobalt(II), Nickle(II) and Copper(II) complexes of 3-amino-5-(4-fluorophenyl)isoxazole derivatives. J Mol Struct. 2019;1202:1-41. doi:10.1016/j.molstruc.2019.127338

56. Ali I, Haque A, Saleem K, Hsieh MF. Curcumin-I Knoevenagel's condensates and their Schiff's bases as anticancer agents: synthesis, pharmacological and simulation studies. Bioorg Med Chem. 2013;21:3808-3820. doi:10.1016/j.bmc.2013.04.018

57. Indumathy R, Kanthimathi M, Weyhermuller T, Nair BU. Cobalt complexes of terpyridine ligands: crystal structure and nuclease activity. Polyhedron 2008;27:3443-3450. doi:10.1016/j.poly.2008.08.003

58. Zhao P, Xu LC, Huang JW, Liu J, Yu HC, Zheng KC, Ji LN. Experimental and DFT studies on DNA binding and photocleavage of two cationic porphyrins: effects of the introduction of a carboxyphenyl into pyridiniumporphyrin. Spectrochim Acta A Mol Biomol Spectrosc. 2008;71:1216-1223. doi:10.1016/j.saa.2008.03.031

59. Hajian R, Ekhlasi E, Daneshvar R. Spectroscopic and electrochemical studies on the interaction of epirubicin with fish sperm DNA. J Chem. 2012;9:1587-1598. doi: $10.1155 / 2012 / 738678$

6o. Campillos M, Kuhn M, Gavin AC, Jensen LJ, Bork P. Drug target identification using side-effect similarity. Science. 2008;321:263-266. doi:10.1126/science.1158140

61. Keiser MJ, Roth BL, Armbruster BN, Ernsberger P, Irwin JJ, Shoichet BK. Relating protein pharmacology by ligand chemistry. Nat Biotechnol. 2007;25:197-206. doi:10.1038/nbt1284

62. Ali A, Khalid M, Rehman MF, Haq S, Ali A, Tahir MN, Ashfaq M, Rasool F, Braga AAC. Efficient synthesis, SC-XRD, and theoretical studies of O-Benzenesulfonylated pyrimidines: Role of noncovalent interaction influence in their supramolecular network. ACS Omega. 2020;5:15115-15128. doi:10.1021/acsomega.oco0975

63. Ooretir C, Kaniskan N. Frontier orbital theory and chemical reactivity: The utility of spectroscopy and molecular orbital calculations. Recent Experimental and Computational Advances in Molecular Spectroscopy. 1993:351-367.

64. Anup Pandith, Young Jun Seo. Label-free sensing platform for miRNA-146a based on chromofluorogenic pyrophosphate recognition. J Inorg Biochem. 2020;203:1-41. doi:10.1016/j.jinorgbio.2019.110867

65. George J, Prasana JC, Muthu S, Kuruvilla TK, Savanthi S, Saji RS. Spectroscopic (FT-IR, FT-Raman) and Quantum mechanical study on N-(2,6 dimehyl phenyl)-2-\{4-[2hydroxy-3(2methoxyphenoxyl)propyl]piperazin-1yl\}acetamide. J Mol Struct. 2018;1171:268-278. doi:10.1016/j.molstruc.2018.05.106 